\title{
COMMENTS
}

\section{Using Severability Clauses to Solve the Attainment Deadlime Dilemma in Environmental Statutes}

\author{
Carolyn McNiven $\dagger$
}

Many of the federal environmental statutes enacted during the last several decades incorporate deadlines specifying the date by which the statutes' goals are to be attained. When attainment deadlines are missed and Congress does not react by amending the statute, courts are left with what the author refers to as the "attainment deadline dilemma": how to enforce obsolete statutory deadlines.

This Comment argues that the best solution to the attainment deadline dilemma is for courts to employ severability clauses in the relevant statutes to remove obsolete deadlines, leaving the remaining statutory language and intent intact. The author focuses on the 1977 Clean Air Act and examines how its enforcement illustrates the inadequacy of courts' past treatment of the dilemma and the advantages of her proposed solution. She then examines the 1990 Amendments to the Clean Air Act and contrasts the solution adopted there to her severability proposal.

\section{INTRODUCTION}

Public concern for our environment has increased exponentially in recent years. We are no longer willing to tolerate free-flowing waste froin factories and industrial plants. The black plume of smoke billowing froin the sinokestack no longer suggests industrial strength and prosperity; instead, it suggests physical harm to ourselves and the environment around us. Pollution has made even raindrops destructive and corrosive.

Over the past four decades Congress has enacted a great deal of

$\dagger$ Law clerk to Judge Paul E. Plunkett, U.S. District Court for the Northern District of Illinois. B.A. 1986, Amherst College; J.D. 1991, Boalt Hall School of Law, University of California, Berkeley. The views expressed here are the author's alone and do not necessarily represent the views of Judge Plunkett or any other person.

The author deeply appreciates the generosity and thoughtful advice of Professor John Dwyer; the inspiration provided by Professor Paul Mishkin; the information gleaned from classroom discussions with Professor Daniel Rodriguez; and the editorial input of the indefatigable Mark Jarrett and Caroline Lee. 
legislation designed to combat the pervasive effects of environmental pollution. Some of these new laws seek to clean up our environment; others seek merely to preserve what remains. All involve complex statutory schemes and have spawned even more detailed regulations.

These environmental statutes share another common feature: deadlines. Some of these deadlines apply to the federal agencies or state and local governments entrusted with the statutes' implementation; others apply directly to the emitters of pollution. The rationale behind including these deadlines is obvious: people "seldom draw the best from themselves unless pressed by circumstances and deadlines." Indeed, Congress often includes deadlines that are unrealistic in hight of current teclinologies and circumstances to force teclinological advances that otherwise might not be achieved. Unfortunately, experience has proven that unrealistic deadlines, although they may mcrease the pace of technological advancement and environmental improvement, generally cannot speed change to the degree necessary to ensure that all deadlines are met.

This built-m potential for failure would not be a problem if the statutes were periodically revised to ensure that the deadlines force technology without becoming obsolete. Disagreements in Congress and the Executive Branch over environmental regnlation, however, have meant that revising the various environmental statutes has been an attenuated and arduous task. In some imstances when legislative stalemates have occurred, portions of the statutes have actually become obsolete: deadlimes have passed without the desired result being accomplished.

This Cominent examines how judges, who must apply these statutes, dealt with this type of obsolescence im a particular instance: the deadlines im the Clean Air Act Amendments of 1977 (also referred to as the 1977 Clean Air Act or "the Act"). This Act, like similar other statutes, contained two types of deadlines-interim and attainment deadlines. Interim deadlines are steps along the route to the statute's goal. In general, they place duties on individual actors. Many statutes make these actors liable for failure to perform their required duties by the interim deadline. Where these penalties are insufficient, a judge may be called upon to employ her equitable powers to ensure enforcement of the statute. As a consequence, the interim measure will be accomplished, albeit behind schedule.

Attainment deadhines depend on the accumulated conduct of multiple actors, the pace of teclinological development, and the accuracy of predictions that compliance with interim measures would lead to timely attainment of the statutory goal. When attainment deadlines are missed, therefore, the solution is not quite so easy: there is no statutory remedy or single guilty party to penalize. I call the problem of enforcing obsolete

1. 117 CoNG. Rec. 38,808 (1971) (statement of Sen. Montoya). 
attainment deadlines the "attainment deadline dilemma." I suggest that the judicial solutions to this obsolescence problein in the context of the Clean Air Act Amendinents of 1977 were largely unsatisfactory and counterproductive.

Obviously a inore satisfactory solution would be timely amendment of these statutes by Congress. As noted above, however, this optimal solution ignores the political difficulties that stymie such amendinent. Because timely amendment is chimerical, courts and enforcing agencies need a principled way to deal with the dilemma. This Comment proposes a solution: whenever Congress enacts attainment deadlines, it should include a severability clause that will allow courts to reinove these deadlines should they becoine obsolete prior to legislative amendment. Where courts inake use of the clause to sever obsolete dates from the statute, the remaining statutory langnage would continue to apply, ensuring expeditious progress towards attainment of the statute's goal. Agencies could use the surviving statutory langnage to plan for attaininent, while courts could use the same language to review the reasonableness of agency plans when they are challenged.

One value of the severability approach is that it takes the political realities surrounding environmental legislation into account. First, it anticipates that updating and revision by Congress may well be delayed due to political deadlock. Second, it recognizes that where the legislature fails to act, courts have only limited powers to resolve statutory obsolescence. Judges cannot do what the legislature inay; namely, update and revise already-enacted laws. Third and finally, it acknowledges that in these circuinstances the executive agency entrusted with the statute's enforceinent is the inost appropriate body to fashion interin updating of the statute tlirough interpretation until Congress is able to enact updating legislation.

Part I of this Comment begins by describing the attainment date dilemma in general terms. It then explores a specific exainple-the Clean Air Act after its 1977 amendinent but prior to its further revision in 1990. It shows how, in this context, widespread attaininent deadline violations gave rise to a plethora of difficulties and unsatisfactory solutions.

Part II outhines a proposed alteruative in which attaminent deadline provisions are simply severed from a statute, leaving sufficient law in place for an agency to impleinent statutory requirements true to that statute's language and spirit. This Part illustrates exactly how this alternative would have worked in the context of the 1977 Clean Air Act, and goes on to suggest that Congress should contemplate the use of severability provisions whenever it writes technology-forcing statutes.

Part III compares the severability solution to two alternative interpretive approaches: dynamic interpretation and textualism. This Part 
shows that the severability solution is preferable to dynamic interpretation because it permits the legislature to control subsequent judicial interpretation of the statute, by defining, in the statute itself, when severability is appropriate and how and to what extent courts must employ these provisions. Part III reveals that the severabihity solution is preferable to textuahsm because it reflects a more sophisticated appreciation of legislative pohtics. This Part concludes with an analysis of the 1990 Amendments to the Clean Air Act and compares the deadline substitution solution included in those Amendments to the severability approach.

\section{I}

An Overview of the Deadline Problem

After 1970, Congress began to mclude a variety of deadlines and timetables im its regulatory statutes im reaction to complaints that earlier legislation had been overly vague. ${ }^{2}$ Legislation regulating pollution einissions and the cleanup of polluted areas was no exception to this general pattern. The deadlines contamed in these environmental statutes are of two main types: interim and attainment.

\section{A. Types of Deadlines}

\section{Interim Deadlines}

Interim deadlines generally specify when an individual polluter, state, or agency must act pursuant to or in compliance with a particular statutory requirement. ${ }^{3}$ For example, an interim deadline for a pollution emitter might be the date by which its emissions must meet regulatory requirements. For a state such a deadlime might be the date by which it must promulgate an implementation plan. In the case of an agency, the statute might require it to promulgate guidelines or standards by a certain date. Even though interim deadlines create affirmative duties, they are not ends in theinselves; they are part of a strategy for achieving the statute's ultimate goal. 7 (1983).

2. R. Shep Melnick, Regulation and the Courts: The Case of the Clean Air Act

3. See, e.g., Federal Insecticide, Fungicide and Rodenticide Act (FIFRA), 7 U.S.C. $\S \S 136 \mathrm{a}(\mathrm{c})(2)-(3), 136 \mathrm{a}-1$ (1988) (amended 1991); Endangered Species Act (ESA), 16 U.S.C. $\S 1533$ (b) (1988); Surface Mining Control and Reclamation Act (SMCRA), 30 U.S.C. $\S \S 1251-1254$ (1988); Federal Water Pollution Control Act (Clean Water Act), 33 U.S.C. $\S \S 1284(b), 1288(a)$, 1289, 1311(c), 1313, 1314, 1316, 1329, 1342 (1988); Ocean Dumping Act (MPRSA), 33 U.S.C. $\S 1414 \mathrm{~b}(\mathrm{a})(1)$, (b)(1)(B) (1988); Solid Waste Disposal Act (SWDA), 42 U.S.C. $\S \S 6907,6921,6922$, 6925, 6930, 6942, 6944 (1988); Comprehensive Environmental Response, Compensation, and Liability Act (CERCLA), 42 U.S.C. $\$ \S 9602,9616$ (1988).

Some statutes give the implementing agency control over the formulation and promulgation of these intermediate deadlines. For an example of a general mandate of this sort, sec Clean Air Act (CAA), 42 U.S.C. $\$ 7410(a)(2)(A)$ (Supp. II 1990) (state implementation plans must include "schedules and timetables for compliance, as may be necessary or appropriate to meet the applicable requirements of this chapter"). 
The reinedy for failure to meet an interim deadline is fairly routine and may even be prescribed in the statute itself. For example, under the 1977 Clean Air Act if a state failed to promulgate an implementation plan or a pollution source failed to obtain a permit, the Environmental Protection Agency (EPA) had authority to take pumitive action. Such punitive action could mclude halting federal funding of new highway construction or bringing a civil or criminal suit against the offender to coinpel coinphance. ${ }^{4}$ Where the agency itself failed to fulfill a nondiscretionary duty, citizen suit provisions, a feature of many environmental acts, ${ }^{5}$ allowed private individuals and environmental groups to take the agency to court to force it to perform its statutory duty. ${ }^{6}$

Because violations of interim deadlines by private polluters are generally handled internally by the responsible agency, most actions that reach courts imvolve allegations of agency violations of nondiscretionary duties. ${ }^{7}$ Where courts have found such violations, they have not hesitated to order the agency to comply with its statutory duties. In some instances the court has ordered the agency to make a long-postponed decision; ${ }^{8}$ in others, the court has created timetables or revised interim deadlimes within which the agency inust act. ${ }^{9}$

4. See 42 U.S.C. $\$ \S 7420,7506$ (1988) (amended 1990); see also FIFRA, 7 U.S.C. $\$ \S 163 \mathrm{~g}(\mathrm{c})$, 163k, 163 l(1988); SMCRA, 30 U.S.C. $\$ \S 1268,1271$; Clean Water Act, 33 U.S.C. $\$ \S 1319$, 1342(h) (1988 \& Supp. II 1990); MPRSA, 33 U.S.C. $\$ \S 1414 b(d), 1415$ (1988); Safe Drinking Water Act (SDWA), 42 U.S.C. $\S \S 300 \mathrm{~g}-3(\mathrm{~g}), 300 \mathrm{~h}-3$ (c) (1988); SWDA, 42 U.S.C. $\S 6928(\mathrm{~d})$, (g) (1988); CERCLA, 42 U.S.C. $\$ \$ 9609,9613$ (1988).

5. See, e.g., ESA, 16 U.S.C. $\S \S 1536(\mathrm{n}), 1540(\mathrm{~g})$ (1988); SMCRA, 30 U.S.C. $\S 1270$ (1988); Clean Water Act, 33 U.S.C. $\S 1365$ (1988); MPRSA, 33 U.S.C. $\$ 1415(\mathrm{~g})(1988) ;$ PHSA, 42 U.S.C. $\S 300$ j-8 (1988); SWDA, 42 U.S.C. $\S 6972$ (1988); 1977 Clean Air Act (1977 CAA), 42 U.S.C. $\S 7604$ (1988) (amended 1990); CERCLA, 42 U.S.C. $\S 9659$ (1988).

6. For a good example of remedying agency neglect through a citizen suit provision, see Natural Resources Defense Council v. New York State Department of Environmental Conservation, 668 F. Supp. 848 (S.D.N.Y. 1987).

7. Where a private source's failure to comply is at issue, some private sources have argued effectively that the agency's failure to perform a nondiscretionary duty, such as the promulgation of guidelines, prevented them from meeting their commitments under the state implementation plan. See Washington v. EPA, 573 F.2d 583, 589 (9th Cir. 1978) (stating that paper mill's permit to discharge sulphite wastes cannot be revoked by EPA Administrator when EPA has not established applicable regulations); National Ass'n of Regional Councils v. Costle, 564 F.2d 583, 591 (D.C. Cir. 1977) (funding of local planning agencies under Federal Water Pollution Control Act Amendments should not be cut because of EPA's failure to meet deadlines mandated by statute); Republic Steel Corp. v. Train, 557 F.2d 91, 97 (6th Cir. 1977) (stating that EPA's failure to publish regulations for alloy and stainless steel manufacturing excused steel producer's noncoinpliance), vacated sub nom. Costle v. Republic Steel Corp., 434 U.S. 1030 (1978).

8. See, e.g., Farmer's Union Cent. Exch. v. FERC, 557 F. Supp. 34, 35 (D.D.C. 1982) (directing an agency to act within 60 days where the agency had unreasonably delayed doing so).

9. For examples of court-imposed timetables, see Pulido v. Heckler, 758 F.2d 503, 508 (10th Cir. 1985) (creating timetable for agency to ensure regulations are promulgated); Natural Resources Defense Council v. Train, 510 F.2d 692, 704 (D.C. Cir. 1975) (explaining that district court's imposition of timetable was reasonable where EPA had failed to meet deadline for promulgating regulations). For examples of court-imposed interim deadlines, see Natural Resources Defense Council v. New York State Department of Environmental Conservation, 668 F. Supp. at 859 app. A 
Courts have employed their equitable powers to enforce a variety of environmental statutes. ${ }^{10}$ In fashioning equitable reniedies for agency violations of mterim deadlimes, courts generally consider the reasons for the delay ${ }^{11}$ and the constraints on agency action; ${ }^{12}$ nevertheless, in some cases these same considerations have been explicitly disregarded. ${ }^{13}$ Where agencies have failed to obey court orders, courts have even been known to slap contempt citations on the agency admimistrator. ${ }^{14}$

\section{Attainment Deadlines}

Courts have not found it as easy to remedy a failure to meet attainment deadlines. Not all environmental statutes have attainment dead-

(setting out timetables that track dispute over which deadlines should be substituted for interim ones that were missed); Natural Resources Defense Council, Inc. v. Train, 4 Envtl. L. Rep. (Envtl. L. Inst.) $20,108,20,108$ (D.D.C. 1973) ("NRDC III") (substituting deadlines by which agency must define best available control technology under Clean Water Act). See also Phillip D. Recd, Marking Time: A Status Report on the Clean Air Act Between Deadlines, 15 Envtl. L. Rep. (Envtl. L. Inst.) 10,022, 10,024-25 (1985) (News \& Analysis) (suggesting that courts have allowed Clean Air Act interim deadlines to be flexible so long as there is no indication this would interfere with attainment deadlines).

10. See, e.g., Environmental Defense Fund v. EPA, 852 F.2d 1309, 1316 (D.C. Cir. 1988) (RCRA case) (finding that EPA did not violate RCRA by deciding not to regulate wastes from extraction); Conservation Law Found. v. Reilly, 743 F. Supp. 933, 938 (D. Mass. 1990) (CERCLA case) (finding that environmental groups had standing to seek relief from EPA's failure to comply with statutory duty to assess federal facilities for hazardous waste), rev'd, $950 \mathrm{~F} .2 \mathrm{~d} 38$ (1st Cir. 1991); Sierra Club v. Gorsuch, 551 F. Supp. 785, 789 (N.D. Cal. 1982) (CAA case) (ordering EPA to propose emission standards for radionucleides within 180 days).

11. See, e.g., Alabama Power Co. v. Costle, 636 F.2d 323, 372 (D.C. Cir. 1979) (stating that agency's excuse for delay must be "justified"); Natural Resources Defense Council v. Train, 510 F.2d 692, 713, (D.C. Cir. 1975) ("We thiuk the court may forbear the issuance of an order in those cases where it is convinced by the official involved that he has in good faith employed the utmost diligence in discharging his statutory responsibilities."); Atlantic Terminal Urban Renewal Area Coalition v. New York City Dep't of Envtl. Proteetion, 740 F. Supp. 989, 998 (S.D.N.Y. 1990) (noting that defendants demoustrated they are "taking all reasonable steps to fulfill [their statutory obligations]").

12. See, e.g., Alabama Power, 636 F.2d at 359 ("The . . . consideration of administrative need to adjust to available resources would apply where the constraint was imposed not by a shortage of funds but, say, by a shortage of time, or of the technical personnel needed to administer a program.") (footnote omitted); $i d$. at 372 ("Of course even a congressional mandate, such as a technologyforcing requirement based on a congressional projection of emergence of technology for the future, is subject to a justified excuse from compliance where good-faith effort to comply has not been fruitful of results."); Natural Resources Defense Council v. Train, 510 F.2d at 712 ("The courts cannot responsibly mandate flat guideline deadlines when the Administrator demonstrates that additional time is necessary to insure that the guidelines are rooted in an understanding of the relative merits of available control technologies.").

13. See New York v. Gorsuch, 554 F. Supp. 1060, 1066 (S.D.N.Y. 1983) (stating that court must grant equitable relief when EPA fails to follow nondiscretionary duty to publish regulations); cf. TVA v. Hill, 437 U.S. 153, 193-94 (1978) (stating that where Congress has mandated the remedy for a violation, equitable relief must follow).

14. See Sierra Club v. Ruckelshaus, 15 Envtl. L. Rep. (Envtl. L. Inst.) 20,101, 20,103 (N.D. Cal. 1984) (holding EPA in contempt for failing to regulate pollutants in accordance with $\S 172$ of the 1977 Clean Air Act). 
lines. ${ }^{15}$ Attainment deadlines expressly stipulate the date by which Congress desires a statute's ultimate goal be achieved. ${ }^{16}$ Unlike interim deadlines, which place affirmative duties on particular entities, attainment deadlines usually call for the final realization of a specified goal such as air or water quality. They thus provide both an outer boundary within which all intermediate steps are meant to be implemented and a final date for the attainment of the intended improvennent of the environinent. For example, the attainment deadlines in the 1977 Clean Air Act mandated when each region of the country was to have met National Ainbient Air Quality Standards for regulated pollutants. In establishing when substantive goals must be achieved, attaininent deadlimes themselves became goals. ${ }^{17}$

\section{a. The Deadlines as Technology-Forcing Devices}

In environmental laws, interim and attainment deadlines are often part of the statute's technology-forcing scheme. A technology-forcing statute intentionally sets high or unrealistic goals to force compainies to use the available technology, to develop technology which currently exists only in theory, and to spend money on the research and developinent of effective pollution control devices. As one scholar points out,

15. Certain statutes, particularly those whose entire purpose is to set up a permitting program, do not contain explicit attainment deadlines. See, eg., FIFRA, 7 U.S.C. $\$ 136$ (1988 \& Supp. III 1991); ESA, 16 U.S.C. $\$ \S 1531-1548$ (1988 \& Supp. II 1990); SMCRA, 30 U.S.C. \$§ 1201-1328 (1988 \& Supp. II 1990); PHSA (Title XIV), 42 U.S.C. $\$ \$ 300$ fo 300 j-25 (1988 \& Supp. II 1990); CERCLA, 42 U.S.C. $\$ \S 9601-9657$ (1988 \& Supp. II 1990). Nevertheless, one could argue that, taken together, the interim steps required by all of the statutes signify the attainment goal. Thus, the attainment deadline would be the date, or range of dates, by which the regulatory permit program would be operating fully as required under the statute. Such an interpretation is not considered elsewhere in this Comment.

16. This Comment's description of attainment deadlines and the problems they pose applies best to the Clean Air Act, the Clean Water Act, and the Solid Waste Disposal Act. These three statutes explicitly require that particular regnlatory standards be achieved by specific dates. The term "attainment date" is not a new or novel one. See, e.g., Train v. Natural Resources Defense Council, 421 U.S. 60, 68 (1975) (employing the term).

17. As one commentator has written, after "dodg[ing] the bullet" of a particular interim deadline, "EPA . . . had another bullet to face, and theoretically a larger one, sinee the [interim deadline] was a step toward a goal, but the attainment deadline was the goal." Reed, supra note 9, at 10,026. Courts have authorized exemptions from interim deadlines so long as attainment deadlines are respected. See, e.g., City of Seabrook v. EPA, 659 F.2d 1349, 1357 (5th Cir. Unit A Oct. 1981) (approving EPA's "conditional approval" of the SIP [State Implementation Plan], despite the statute's requirement of final EPA approval by that date, since this still fell within the statute's essential requirement to attain NAAQS as expeditiously as practicable within the attainment deadline: "Conditional approval' [of SIPs] is neither an exemption from this condition nor an extension of the statute's [attainment] deadlines; instead, it is a conclusion that, if minor changes are made, the statute's principal condition and deadlines will be met."), cert. denied, 459 U.S. 822 (1982). Seabrook's reasoning has been followed by several other courts. See Phillip D. Reed, Circuit Courts Endorse Conditional SIP Approval: Connecticut's Construction Ban, 12 Envtl. L. Rep. (Envtl. L. Inst.) 10,055 (1982) (News \& Analysis). But see Republic Steel Corp. v. Train, 557 F.2d 91, 95 (6th Cir. 1977) (suggesting that interim deadlines were crucial aspects of the statutory scheme), vacated sub nom. Costle v. Republic Steel Corp., 434 U.S. 1030 (1978) . 
" $[F]$ or some pollutants in particular industries there may be no existing or theoretical control technology; the control of pollution will then require the developinent of entirely new control equipment or manufacturing processes-that is, it will be necessary to force major technological innovation." 18

The underlymg premise of a technology-forcing strategy is that industries inust be goaded into developing new technologies that reduce negative externalities rather than increase profits. As Senator Montoya has explamed:

Our legislation contains an important principle of psychology: Men seldom draw the best from themselves unless pressed by circumstances and deadlines. This bill contains deadhines and it imposes rather tough standards on industry, municipalities, and all other sources of pollution. Only under such conditions are we hikely to press the technological threshold of invention into new and imaginative developments that will allow us to meet the objectives stated in our bill. ${ }^{19}$

The relative success of technology-forcing strategies is debatable. Some critics believe that technology-forcing is fundamentally at odds with the health-based standards at the heart of most environmental legislation. Other opponents argue that combining technology-forcing strategies with health-based standards may not result im desired improvements in technology. ${ }^{20}$ Researchers who have examined the actual use of technology-forcing strategies in detail have even suggested that employing such a method may endanger the public's health because the resulting regulation may be based on incorrect technical assessments. ${ }^{21}$ Despite the debate over the efficacy of forcing technology by including deadlines that may be impossible to meet, the 1990 Amendments to the Clean Air Act are recent evidence that Congress remains wedded to the concept.

As detailed above, one major problem with including technologyforcing deadlines has been that they pass-without the statutory requirements having been met-before Congress acts to revise them. When judges and agency officials were called upon to interpret the 1977 Clean Air Act after its attainment deadlines passed without the required air

18. D. Bruce La Pierre, Technology-Forcing and Federal Environmental Protection Statutes, 62 IoWA L. REV. 771, 773 (1977) (footnotes omitted).

19. 117 CONG. REc. 38,808 (1971) (statement of Sen. Montoya).

20. La Pierre, supra note 18 , at $790-91$.

21. Researchers Downing and Brady state:

It would appear that a high degree of precision in technical control effects estimates is necessary in order to implement the law through this approach. In fact such precision does not exist; all estimates of necessary emission reductions and of the effectiveness of control technologies are highly uncertain, though the EPA has repeatedly used iuformation of questionable accuracy as if it were absolutely true.

Paul B. Downing \& Gordon Brady, Implementing the Clean Air Act: A Case Study of Oxidant Control in Los Angeles, 18 NAT. Resources J. 237, 238 (1978). Downing and Brady quote a director of an air quality bureau as calling this phenomenon "Garbage In-Gospel Out." Id. (footnote omitted). 
quality being achieved in some areas, they reacted with understandable consternation. Years before this dilemma arose, Judge Friendly captured the frustration judges feel when statutes lapse into obsolescence: "I . . . do not at all lament the diminished role of the judge vis-à-vis the legislator as a maker of law. What I do lament is that the legislator has diminished the role of the judge by occupying vast fields and then has failed to keep them ploughed." $\$ 22$

\section{b. The Particular Problems Posed when Attainment Deadlines Become Obsolete}

Judges have encountered the greatest difficulty when attainment deadlines become obsolete, for although courts can alter interim deadlines by ordering post-imterim-deadline compliance, they cannot do this with respect to attainment deadlines. First, successful achievement of an attainment deadhine is not a question of a particular actor fulfilling its statutory duty. While interim deadlines are keyed to the affirmative actions of a particular group or institution, attainment deadlines specify when a certain situation-beyond the control of any single actor-must exist. Unlike intermediate steps, attainment cannot be "ordered" by a court, state, or agency. A court can tell a state that it has failed to submit a plan by an mterim deadline, but it cannot magically create compliance with clean air or water standards merely by commanding the situation into being.

Attainment of the statutory goal depends on all regulated actors fulfilling their duties, the pace of the development of pollution control technologies, and on the accuracy of the predictions upon which implementation decisions have been made. One actor, such as the agency, may appear to be the main inhibitor of progress, but this is only true if all other actors, such as the state or the emitters, have fulfilled their duties and if their activities would have produced the expected benefit but for the violations of the suspected offender. When attainment deadlines have been missed, the interdependence of this multitude of actors has strained courts' equitable powers to fashion an appropriate remedy.

Second, it is clear that a violation of an interim deadline by one or more actors does not inake that deadline obsolete. That deadline may still be used to assess noncompliance penalties and fashion equitable relief, if needed, with respect to those violators. ${ }^{23}$ In contrast, statutes do

22. Henry J. Friendly, The Gap in Lawmaking-Judges Who Can't and Legislators Who Won't, 63 CoLUM. L. Rev. 787, 792 (1963).

23. If an agency fails to complete its mandated duties before the expiration of an interim deadline, there is an issue of whether the agency still retains authority to act. Faced with this issue, courts have searched applicable legislative histories in efforts to uphold agency actions after "cut off" dates. See Linemaster Switch Corp. v. EPA, 938 F.2d 1299, 1309 (D.C. Cir. 1991) ("Congress did not intend to suspend EPA's authority to add sites to the [National Priorities List under the CERCLA statutes] even though the agency failed to meet the statutory ... deadline ....."); see also 
not make clear what force, if any, an attainment deadline has once it passes without attainment occurring. Since no environmental statute provides for post-deadline attainment planning, it is unclear what role the missed deadline should play im enforcing the statute. Despite this problem of obsolescence, courts cannot merely revise out-of-date attainment deadlines. Given the centrality of these deadlines to the statutory scheme, ${ }^{24}$ changing an attainment deadline without statutory authority to do so might appear to be an impermissible assumption of legislative power, akin to Congress' amendment power. ${ }^{25}$ A court-ordered or courtsanctioned substitute deadline is especially problematic because the court would no longer be saying what the law is-the traditional conception of the judicial function-but saying what the law should be. ${ }^{26}$

This is only a thumbnail sketch of the attainment deadline dileinma. The next Section will examine a specific example in greater detail: the Clean Air Act as amended in 1977 and prior to its 1990 ainendment. ${ }^{27}$

Brock v. Pierce County, 476 U.S. 253, 260 (1986) ("When, as here, there are less drastic remedies available for failure to meet a statutory deadline, courts should not assume that Congress intended the agency to lose its power to act.") (footnote omitted).

24. See, eg., Union Elec. Co. v. EPA, 427 U.S. 246, 258 (1976) ("Seetion 110(a)(2)(A)'s threeyear deadline for achieving primary air quality standards is central to the Amendments' regulatory scheme and, as both the language and the legislative history of the requirement make clear, it leaves no room for claims of technological or economic infeasibility."); Train v. Natural Resources Defense Council, 421 U.S. 60, 66-67 (1975) ("Probably the principal of these conditions, and the heart of the 1970 [Clean Air Act] Amendments, is that the plan provide for the attainment of the [NAAQS] in the particular state 'as expeditiously as practicable but ... in no case later than three years from the date of the approval of such plan." ") (quoting $\S 110(\mathrm{a})(2)(\mathrm{A})$ of the $1970 \mathrm{Act}$ ) (emphasis added); City of Seabrook v. EPA, 659 F.2d 1349, 1357 (5th Cir. Unit A Oct. 1981) ("The 'heart' of the 1977 Amendments is that the SIP ... 'shall provide for attainment [of the NAAQS] . . not later than December 31, 1982.' ") (quoting the 1977 Clean Air Act, 42 U.S.C. $\$ 7502($ a)(1) (Supp. 1980)), cert. denied, 459 U.S. 822 (1982). But see infra note 153 (suggesting that the court may have been referring to all the statutory requirements, not just the deadlines).

25. This position was articulated by the Ninth Circuit in Delaney v. EPA, 898 F.2d 687, 690 (9th Cir.), cert. denied, 111 S. Ct. 556 (1990).

One could argue that Congress approved the practice of resetting interim deadlines by failing to act in the face of court action. This congressional practice is called adoption by legislative inaction. See Bob Jones Univ. v. United States, 461 U.S. 574, 599-602 (1983); see also Commissioner v. Engle, 464 U.S. 206, 225 (1984); Guardians Ass'n v. Civil Serv. Comm'n, 463 U.S. 582, 593 n.14 (1983). See generally William N. Eskridge, Jr., Interpreting Legislative Inaction, 87 Mich. L. REV. 67 (1988); Daniel A. Farber, Statutory Interpretation, Legislative Inaction, and Civil Rights, 87 MicH. L. REV. 2 (1988). Although one might presume Congress has adopted the practice of rewriting interim deadlines by failing to correet the courts, one cannot make a similar presumption regarding attainment deadlines, since no court has yet tried to rewrite one.

26. EPA has articulated a similar concern that its own revision of deadlines may constitute an unwarranted intrusion on congressional authority. 53 Fed. Reg. 49,494, 49,512 (1988).

27. Prior to its recent amendment, the Clean Air Act had not been amended since 1977. In order to minimize confusion with the new version of the Act, I will refer to the 1977 version as the "1977 Clean Air Act." The original Clean Air Act was Pub. L. No. 88-206, 77 Stat. 392 (1963). The Act was subsequently amended by the Clean Air Act Amendments of 1966, Pub. L. No. 89-675, 80 Stat. 954; the Clean Air Act Amendments of 1970, Pub. L. No. 91-604, 84 Stat. 1676; the Clean Air Act Amendments of 1977, Pub. L. No. 95-95, 91 Stat. 685; and most recently, by the Clean Air Act Amendments of 1990, Pub. L. No. 101-549, 104 Stat. 2684. For a thorough treatment of the legislative histories of state and federal air pollution control laws from their beginnings until 1977 , 
This Act provides an apt focus on our larger problem for a number of reasons. First, the 1977 Clean Air Act was one of the "new" major regulatory statutes of the 1960 s and 1970 s and has had a significant impact on both the economy and the environment. ${ }^{28}$ Second, the Act contained both interim and attainment deadlines. Third, the failure of some regions of the country to attain air quality standards by the statutory attaininent deadhines posed the attainment deadline dilemma in particularly stark terms. Fourth, EPA's activities with respect to these regions were challenged in court with paradoxical results. Finally, although Congress lias recently amended the Act in an atteinpt to evade the deadline dilemina, the solution it contains-a deadline substitution planmay ultinately prove illusory if attaininent is not achieved prior to the substitute deadlines. Indeed, one of this Comment's principal argnments is that the attamment deadline dileinina will recur so long as statutes are merely updated by replacing deadlines after they have passed with new technology-forcing ones.

\section{B. The Problem as Presented by the 1977 Clean Air Act}

\section{Anti-Pollution Legislation Before the 1977 Act}

The earliest attempts to control air pollution date back to the nimeteenth century and were inade at the state and local level. ${ }^{29}$ During the post-war decades, federal officials gradually began to address the problein of air pollution..$^{30}$ Dissatisfaction with the measures adopted by state governments and increasing public awareness of environmental issues led to the passage of the landmark Clean Air Act Amendinents in 1970. ${ }^{31}$

These Amendments had three basic objectives: "First, to achieve air quahty which would protect public health; second, to establish specific regulatory requirements and precise timetables for achieveinent of those requirenents; and third, to establish long-term public policy goals for air quality prograins." ${ }^{32}$ The addition of deadlines was an intentional and key feature of the 1970 Act. As Senator Muskie, the Act's chief author, later commented: "We proposed and saw enacted in 1970 two basic tools-controls on elnissions and establishment of deadlines. Emission

see Arthur C. Stern, History of Air Pollution Legislation in the United States, 32 J. AIR Pollurion CoNTROL Ass'N 44 (1982); see also Train v. Natural Resources Defense Council, 421 U.S. at 63-67 (detailing the early federal efforts).

28. See MELNICK, supra note 2, at 18-19.

29. See Stern, supra note 27 , at 44-48.

30. See generally James E. Krier \& Edmund Ursin, Pollution and Policy: A Case Essay on California and Federal Experience with Motor Vehicle Air Pollution 1940-1975 passim (1977); MeLNICK, supra note 2, at 24-52; Stern, supra note 27, at 48-61.

31. The Clean Air Act Amendments of 1970, Pub. L. No. 91-604, 84 Stat. 1676; see KRIER \& URSIN, supra note 30, at 200-01; MELNICK, supra note 2, at 28; Stern, supra note 27, at 55.

32. 123 CoNG. REC. 18,014 (1977) (statements of Sen. Muskie), reprinted in 3 STAFF of Senate Comm. on Env't and PUb. Works, 95th Cong., 2D Sess., A Legislative History of the Clean Air ACt Amendments of 1977, at 706 (Comm. Print 1978). 
controls replaced air quality standards as the enforcement mechanism; and deadlines provided the public with a basis against which to judge progress." 33

The impetus behind the addition of deadlines was clear. By 1970 both industrial leaders and state officials were accused of dragging their feet in taking steps to remedy the nation's chronic air pollution. Americans became mcreasimgly worried about the "environmental crisis" and expressed their concern that spring by holding Earth Day activities nationwide. ${ }^{34}$

Congress no longer considered it sufficient to provide guidelines or even to prescribe a set of compulsory behavioral rules to state governments and polluters. Instead, the legislators decided to guarantee the quality of the nation's air by mandating that these actors achieve particular results under deadlines. Moreover, the legislators wanted to force technological advances by imposing demanding deadlines. ${ }^{35}$ Automobile manufacturers were to reduce pollution emissions in new cars by ninety percent withm five years; ${ }^{36}$ state governments were to achieve national air quality standards for regulated pollutants within three years, or with federally approved extensions, withm five years. ${ }^{37}$ Hopes were high. As Senator Edmund Muskie confidently told the Senate in 1970: "[A]11 Americans in all parts of the country shall have clean air to breathe within the 1970's." 38

\section{The 1977 Clean Air Act}

Although the 1970 Act enjoyed a measure of success, it soon became clear that certain regions of the country were far from meeting the Act's goal in time to comply with its attainment deadhines. Congress amended the Act in 1977 to strengthen the existing federal and state partnership for cleaning the nation's air and to create new measures for problematic regions. Once agam deadlines were a key feature of the statutory scheme. As Senator Muskie stated, "Only by requiring such a clear connection between the health standards and the deadlines can enforcement

33. Id.

34. See KRIER \& URSIN, supra note 30, at 200-03. Sen. Edmund Muskie, the Act's chief author, pushed the Amendments through Congress, motivated at least partly by a desire to salvage his political reputation after Ralph Nader's Center for Responsive Law released a study criticizing Muskie's efforts to support air pollution legislation. Id. at 203. Nader had begun his attack on the automobile industry five years earlier. See RALPH NADER, UNSAFE AT ANY SPEED: THE Designed-in Dangers of the AMERICAN AUtomobile (1965).

35. See Union Elec. Co. v. EPA, 427 U.S. 246, 256-59 (1976) (discussing the technologyforcing quality of the deadlines and quoting various legislators).

36. See KRIER \& URSIN, supra note 30, at 205-06; MELNICK, supra note 2, at 28-29; Stern, supra note 27 , at 55 .

37. KRIER \& URSIN, supra note 30 , at 205.

38. 116 CONG. REC. 42,381 (1970) (remarks of Sen. Muskie), quoted in David Schoenbrod, Goals Statutes or Rules Statutes: The Case of the Clean Air Act, 30 UCLA L. REv. 740, 746 (1983). 
of the act be effective."39 This sentiment was echoed by EPA's General Counsel, who concluded that "if the firm statutory deadlines are nullified, every air pollution control measure imposed by EPA or a State would be held hostage to legal challenges and possible reversals on grounds of judicially perceived 'reasonableness." "40 Commensurate with the Act's technology-forcmg design, the 1977 Amendments' deadlines were intended to hold industry's feet to the fire.

In addition to deadhines, the 1977 Amendments included specific provisions for regions that were having difficulty complying with air quality standards and emission controls. The Amendments called these regions "nonattainment areas." The 1977 Amendments extended the deadlines of the 1970 Act for these nonattamment areas but imposed additional demands on them. In addition, the Amendments expanded several anti-pollution programs and strengthened penalties for violations.

The basic structure of the 1970 Act, however, remained unaltered. The amended Act required the Admmistrator of EPA to promulgate National Ambient Air Quality Standards (NAAQS) for certain specified pollutants. ${ }^{41}$ The NAAQS for a regulated pollutant, ${ }^{42}$ still in effect after the 1990 Amendments, represent the higliest concentration in which a pollutant may be present in the ambient air without larming the public health, allowing also for an adequate inargin of safety. ${ }^{43}$

The Act's goal was that all regions have air in whicli pollutants are below the federal standards. To attain this goal, section 110 of the Act required states to subimit to federal review a "State Implementation Plan" (SIP). ${ }^{44}$ The SIP had to contain emission limitations for specific categories of pollutant sources, schedules and timetables for compliance,

39. 123 CONG. REC. 18,017 (1977) (statement of Sen. Muskie).

40. Id. at 715 (quoting a legal memorandum prepared by EPA General Counsel). Quoted in full, the excerpted legal memorandum stated,

It is clear from the Union Electric case and Train $v$. Natural Resources Defense

Council, 95 S. Ct. 1470 (1975), that the Supreme Court found the Act to be of a technology forcing character primarily because of its firm deadlines. And it is clear that the Court in Texas v. EPA, 499 F.2d 289 (5th Cir. 1974) would not have upheld stringent vapor recovery regnlations for ship[s] and barges, for which the Court (per Bell J.) recognized that the "necessary technology is not presently available," were it not for the Act's "absolute command that the national ambient air quality standards be met by 1977." 499 F.2d at 312,317 . In fact, Judge Bell's decision required EPA to postpone certain measures not deemed reasonable by the Court until the final statutory attainment date. This decision bolsters our concern that if the firm statutory deadlines are nullified, every air pollution control measure imposed by EPA or a State would be held hostage to legal challenges and possible reversals on grounds of judicially-perceived "reasonableness." The net effect could only be further delays in ever attaining the Act's health standards.

Id.

41. 42 U.S.C. $\$ 7409(a)(1)(B)(1988)$.

42. There currently are six regulated pollutants. See infra text aceompanying notes 223-24.

43. 42 U.S.C. $\$ 7409$ (b)(1) (1988).

44. Id. \$7410 (amended 1990); see 42 U.S.C. § 7407(a) (1988) ("Each State shall have the primary responsibility for assuring air quality within the entire geographic area comprising such State by submitting an implementation plan for such State which will specify the manner in which [NAAQS] will be achieved and maintained within each air quality control region ....."). 
and "such other measures as may be necessary to insure attainment and maintenance [of the NAAQS]."45 These "other measures" included transportation controls, air quality maintenance plans, and preconstruction review of direct sources of air pollution. ${ }^{46}$

As mentioned above, the 1977 Amendments set certain outer limits on when the goal of clean air had to be attained. Since these attainment deadlines are at the core of our examination of the obsolescence problem, their structure is important to understand. The SIP had to provide for the attainment of each NAAQS "as expeditiously as practicable but ... in no case later than three years from the date of approval of such plan." 47 Soine extensions were allowed beyond this three year deadline. A state governor could apply to EPA's Admimistrator for an extension of up to two years for a particular air quality control region. ${ }^{48}$ The Administrator could grant the extension only after finding that:

(A) one or more emission sources (or classes of moving sources) are - unable to comply with the requirements of such plan which implement such [NAAQS] . . . because the necessary technology or other alternatives are not available or will not be available soon enough to permit compliance within such three-year period, and

(B) the State has considered and applied as a part of its plan reasonably available alternative means of attaining such [NAAQS] . . . and has justifiably concluded that attainment ... within the three years cannot be achieved. ${ }^{49}$

Where an extension was granted, the 1977 Amendments required that the state plan include regulations for the region's other pollutant sources irrespective of whether they were the culprits in nonattainment. Plans governing extension areas also liad to include all interim measures for the problematic pollution sources that were reasonable under the circumstances. ${ }^{50}$

The 1977 Amendinents also specified that no major stationary source of airborne pollutants could be constructed or inodified after June 30,1979 , in any regional area failing to ineet air quality standards, if that source was emitting any of the pollutants causing the failure. ${ }^{51} \mathrm{~A}$ state could avoid sucli a construction ban if it included a permit prograin pursuant to part D of the Act (entitled "Plan Requirements for Nonattaininent Areas") in its SIP. ${ }^{52}$

Part $\mathrm{D}$ required major stationary sources to obtain state permits in

45. Id. $\$ 7410(\mathrm{a})(2)(\mathrm{B})$ (amended 1990).

46. Id.

47. Id. $\S 7410(\mathrm{a})(2)(\mathrm{A})$.

48. Each state is made up of air quality control regions. The SIPs contain separate provisions for these regions varying according to regional conditions.

49. 42 U.S.C. $\$ 7410(e)(1)$ (1988) (repealed 1990).

50. Id. $\S 7410(\mathrm{e})(2)(\mathrm{B})$.

51. Id. $\$ 7410(\mathrm{a})(2)(\mathrm{I})$ (amended 1990).

52. Id. 
nonattainment areas. It required that the SIP provide for "attainment of each such national ambient air quality standard in each such [nonattainment] area as expeditiously as practicable, but, in the case of national primary ambient air quality standards, not later than December 31 , 1982." 53 Part D specified only one exception to this general rule: if a state could demonstrate to the Administrator's satisfaction that either the carbon monoxide or ozone standards (or both) could not be met by the 1982 deadline, the Administrator could extend the attainment deadlines for those pollutants to December 31, 1987..$^{54}$ Congress later extended the part $\mathrm{D}$ deadline for areas given an extension due to ozone and/or carbon monoxide nonattainment to August 31, 1988.55

Part $\mathrm{D}$ required nonattainment areas to implement "all reasonably available control technology" (RACT); to monitor actual emissions from all sources; to identify the additional emissions that a new or modified major stationary source would contribute; to requirc permits for the construction and operation of such sources; to set schedules for comphance; and to demonstrate that manpower, financial resources, local government, and regulations were committed to attaining the goal. ${ }^{56}$ Areas granted extensions to the 1987 (later 1988) deadhine had to employ, in addition, a stricter permit program for new sources, an inspection and maintenance program for auto emission devices, and whatever additional measures were necessary to ensure meeting the extended attainment deadline. ${ }^{57}$ The 1977 Amendments contained no provisions for regions that did not meet the applicable statutory attainment deadline.

If a state failed to submit an SIP meeting the Administrator's approval, EPA had the power under section 110(f) to adopt a "Federal Implementation Plan" (FIP) for the state or metropolitan area with a deficient SIP. ${ }^{58}$ The Act permitted citizens to sue to enforce the requirements of the Act if they believed any government or private source had violated its provisions. 59

Despite these amendments, a number of areas failed to meet all of the air standards by the new attainment deadlines. As detailed above,

53. Id. § 7502(a)(1) (emphasis added).

54. Id. \& 7502(a)(2).

55. Pub. L. No. 100-202, 101 Stat. 1329-199 (1988). In the same bill, Congress postponed until August 31, 1988, the construction ban that would have gone into effect in areas in nonattainment for carbon monoxide and ozone under the original 1987 deadline. Id.

56. 42 U.S.C. $\S 7502$ (b) (1988) (amended 1990).

57. Id. $\S 7502(\mathrm{~b})(11)$.

58. Id. $\S 7410(\mathrm{c})$.

59. The 1977 Clean Air Act, 42 U.S.C. \& 7604(a)(1) (amended 1990, effective 1992), provided that any person may bring a civil action against any person or government which violates an emission standard or fails to obtain a required permit, or against the EPA Administrator, if that Administrator has failed to perform a nondiscretionary duty under the Act. Id. For a description of one court's requirements for sufficient pleadings according to this provision, see Council of Commuter Organizations v. Metropolitan Transportation Authority, 683 F.2d 663, 670-73 (2d Cir. 1982). 
part $\mathrm{D}$ gave clear directives to agencies and states about the steps to be taken towards controlling pollution in nonattainment areas prior to the attaininent deadlines. However, on its face, the statute gave no indication of what ought to be done if a nonattainment area failed to attain air quality standards by the deadlines.

Relief froin Congress to solve this statutory gap was long in coming. After 1981, Congress inade repeated attempts to ainend the Act and to replace the obsolete attainment deadlines with new ones. ${ }^{60}$ New deadlines were agreed upon relatively early in the amendment process. Congress, however, deadlocked over other provisions, especially those concerning acid rain, and did not pass the whole legislation until $1990 .^{61}$ Consequently, bétween January 1, 1983, and November 15, 1990, many nonattainment areas confronted the attainment deadline dilemma: they were stuck with unrealistic deadlines that were never met, yet they had no statutory language to follow to plan for the post-deadline period.

\section{Solutions Proposed by the Agency and Court Ranged from the Questionable to the Disastrous}

Under the terms of the statute, EPA had a nondiscretionary duty either to approve or to disapprove state implementation plans. If disapproved plans were not satisfactorily revised within a certain period, EPA had a further duty to create an FIP. EPA's problem after an attainment deadline passed was that it either had to approve an SIP that clearly could not provide for attainment by an already obsolete deadline or it had to create an FIP with the same defect. Even before any attainment deadlines had come and gone, citizens and environmental groups had used the 1977 Clean Air Act's citizen suit provision to force EPA to honor its nondiscretionary duties. ${ }^{62}$ Once the final attainment deadlines arrived without attainment, EPA's position became even more vulnerable. The Agency became an inviting target for a variety of plaintiffs.

60. For information about the deadlock, see generally The Congressional Quarterly for 1981 to 1990. E.g., 46 CoNG. Q. 2722 (Oct. 1, 1988) (explaiming that factions killed a possible compromise in 1988); 46 CoNG. Q. 2812 (Oct. 8, 1988) (describing the continuing deadlock over the Clean Air bill); 46 CoNG. Q. 3127 (Oct. 29, 1988) (stating that Congress had been in deadlock over the Clean Air bill since 1982); 47 CoNG. Q. 2381 (Sept. 16, 1989) (describing 1989 fight); see also John P. Dwyer, The Pathology of Symbolic Legislation, 17 EcoloGY L.Q. 233, 266 n. 146 (1990) (describing the mechanics of the deadlock).

61. See 46 CoNG. Q. 2722 (Oct. 1, 1988) (stating that a compromise was killed by a dispute over acid rain provisions). The Amendments were passed on November 15, 1990, as Pub. L. No. 101-549, 104 Stat. 2399 (1990).

62. See, e.g., American Lung Ass'n v. Kean, 670 F. Supp. 1285, 1292 (D.N.J. 1987) (imposing a timetable on New Jersey for compliance with the Clean Air Act), aff'd, 871 F.2d 319 (3d Cir. 1989). 


\section{a. Courts Could Ignore the Deadlines in Easy Cases}

Where a missed attainment deadline was the subject of litigation, courts were largely willing to grant a de facto extension if the region was close to attainment and state and local officials had made good faith efforts to implement the measures estabhished under the SIP. ${ }^{63}$ I call these near-attainment scenarios the "easy" cases. Even in these situations, courts only granted de facto extensions and almost always held that the requirements of part D-the adoption of RACT and attainment "as expeditiously as practicable"-had to contimue to be implemented despite the passage of the deadline. In fashioning remedies for these easy cases, courts relied on their traditional equitable powers rather than on any authority furnished to them by the statute. The courts essentially refornulated the deadlimes on the basis of practical necessity, extendimg them to a date by which states conld adopt RACT and meet air standards "as expeditiously as practicable" in their attempts to reach attainment. However, no court ever went so far as to write the deadlines out of the statute as a matter of law.

American Lung Association v. Kean ${ }^{64}$ is an example of one such easy case. In American Lung, a district court approved a portion of New Jersey's SIP by focusing on the requirement that implementation had to be attaimed "as expeditiously as practicable" rather than by the statutory attainment date (im this case a hittle over one month away). On appeal, the Third Circuit upheld the district court's solution, explaining: "The district court was thus presented with the task of revising the schedule, consonant with the purpose of the Clean Air Act, to ensure that New Jersey came into compliance with the ozone NAAQS 'as expeditiously as practicable." "65

A similar "purposive"66 reading of the statute was reached in Bethlehem Steel Corp. v. EPA, ${ }^{67}$ where the appellate court found that the requirement of adopting RACT did not expire with the passage of the statutory deadline. Indeed, the court noted, "Indiana's failure to achieve timely compliance with the national air quality standards makes it more rather than less needful that its polluters adopt reasonably available con-

63. E.g., sources cited supra note 12; see also Barry Commoner, Failure of the Environmental Effort, 18 Envtl. L. Rep. (Envtl. L. Inst.) 10,195, 10,196 (1988) (News \& Analysis) (asserting that EPA allowed urban areas to miss the deadline for meeting carbon monoxide and ozone ambient air standards).

64. 670 F. Supp. 1285 (D.N.J. 1987), aff'd, 871 F.2d 319 (3d Cir. 1989).

65. American Lung Ass'n v. Kean, 871 F.2d 319, 327 (3rd Cir. 1989).

66. A "purposive" reading of a statute, in tlis context, refers to interpreting a statute in light of its overall purpose, in such a way that its purpose is furthered rather than hampered. This technique is often associated with the work of Hart and Sacks. See HENRY M. HART \& ALBERT M. Sacks, The Legal Process: Materials in the Making and Application of Law 166-67, 1157 (1958).

67. 782 F.2d 645 (7th Cir. 1986). 
trol technology."68 Like the American Lung court, the Bethlehem court chose to ignore some langnage-the deadlines-while upholding what remained. Inplicit in the opinion was the conclusion that the requirement of reasonably available control technology and the mandate of attainment "as expeditiously as practicable" still had force despite passage of deadhines.

Both courts appealed to pragmatism to justify the use of their equitable powers. They and others who followed their lead reasoned that their solutions furthered the purpose of the statute-cleaning the air so that the NAAQS were attained as expeditiously as practicable. Courts were confident that the "as expeditiously as practicable" standard had a judicially determinable meaning and that the legislative purpose could be separated from the specific statutory deadlines. Some courts also noted that part $\mathrm{D}$ requirements should continue to be imposed beyond the deadlines in the interests of fairness; otherwise, intransigent polluters, who did not adopt RACT, would end up being treated inore lenientlywith inore time to comply and no requirement to employ such technologies-than polluters who had abided by the RACT requirement prior to the deadline. ${ }^{69}$

\section{b. The Severe Problem in Los Angeles Highlighted the Dilemma}

Although judges employed this practical, problem-solving approach in many cases of attainment date violation, they were forced to come to terms with the limitations of this approach in dealing with attaininent date planming for the Los Angeles area. Los Angeles did not present an easy case. ${ }^{70}$ The region's topography, weather conditions, industrial output, and dense population created an air pollution problem of imposing magnitude. ${ }^{71}$ Evidence indicated that alınost everyone in the Los Angeles Basim had experienced some physical effects from airborne pollutants. ${ }^{72}$

68. Id. at 651 .

69. See, e.g., id.

70. For an accessible assessment of the Los Angeles problem, see KRIER \& URSIN, supra note 30. See also Alan C. Lloyd et al., Air Quality Management in Los Angeles: Perspectives on Past and Future Emission Control Strategies, 39 J. AIR Pollution CONTROL Ass'N 696 (1989) (discussing revisions to the South Coast Air Quality Management Plan assessing previous emission control measures and describing the anticipated role of new technologies); Charles Lockwood \& Christopher B. Leinberger, Los Angeles Comes of Age, AtLANTIC Monthly, Jan. 1988, at 31, 32, 47 (discussing problems facing Los Angeles, including sinog and other environinental concerns).

71. For a scientific explanation of the genesis of smog, see SAMUEL WILliamSON, Fundamentals of AIR Pollution 158-64, 300-05 (1973) (explaining inversions, which keep smog near the earth's surface, and describing the chemical reactions that cause smog).

72. Eye irritation is the inost common complaint. See id. at 306 (suggesting that $75 \%$ of the Basin's population has experienced smog-induced eye irritation). But there may also be more serious effeets. The presence of particulate matter in the air has been linked to higher inortality rates, prevalence of chronic respiratory diseases, the incidence of acute respiratory illness, and reduced lung function. 2 Energy Resource Consultants, The Benefits of Air Pollution Control 
Los Angeles thus presented an extreme, though not unique, example of a region whose air pollution problem could not be wrestled into attainment at any time near the deadlines. It required a longer-term solution. Despite the unusual severity of its pollution problem, the South Coast Air Basin, in which Los Angeles is located, was under the same part $\mathbf{D}$ mandate to attain compliance as other less severe nonattainment areas. Predictably, the Basin was unable to reach the NAAQS by the August 31, 1988, deadline. ${ }^{73}$ Most experts believe that even applying the strictest controls currently available, attainment is still at least twenty years away. $^{74}$

\section{i. EPA Compelled to Disapprove the SIP and Promulgate an FIP}

In 1984, Mark Abramowitz sued EPA under the Clean Air Act's citizen suit provisions. ${ }^{75} \mathrm{He}$ claimed that EPA had exceeded its authority by approving portions of Califorma's SIP relating to the South Coast Air Basm without a showing that ozone and carbon monoxide limits would be attained by the then-statutory deadline of $1987 .{ }^{76}$ The Court of Appeals for the Ninth Circuit agreed and on November 7, 1987, ordered EPA to disapprove the SIP provisions. ${ }^{77}$ Complying with this court order, EPA began the process required by section $110(a)(2)(A)(1)$ for halting construction in the Basin. The ban was delayed by Congress, but finally took effect on August 31, 1988. ${ }^{78}$

In early 1988, the Coalition for Clean Air and the Sierra Club also sued EPA, claiming that without an SIP currently in effect for the Basin, the Agency had a nondiscretionary duty under the Act to promulgate a federal plan (an FIP). ${ }^{79}$ EPA reluctantly recognized that it did lave such a duty, and the Ninth Circuit affirmed the Agency's conclusion by

IN California 5-8 (1986). Health effects associated with ozone include reduced lung function, aggravation of chronic respiratory conditions, higher incidence of acute eye and respiratory irritation and illness, impairment of athletic performance, and a higher prevalence of chronic respiratory conditions. 2 id. at 5-46; see also UCLA Sch. of Medicine and Pub. Health, Relationship Between Air Quality and the Respiratory Status of Asthinatics in an Area of High Oxidant Pollution in Los Angeles County 3 (Apr. 1, 1987) (unpublished report prepared for the California Air Resources Board) (showing statistically significant changes in the respiratory function of asthmatics correlated to changes in air quality).

73. Despite strict federal legislation and even stricter state laws, air quality in the South Coast Air Quality Management District has only improved for a few pollutants. Lloyd et al., supra note 70, at 696-98 (noting that, as of 1989 attainment levels had been reached for sulfur dioxide and lead and nitrogen dioxide was only two percent from attainment, but carbon monoxide, particulate matter, and ozone levels were far from attaininent).

74. Id. at 698; see 53 Fed. Reg. 49,502 (1988) (stating that the South Coast Air Quality Management Plan aims to achieve attainunent of the ozone NAAQS by 2007).

75. Abramowitz v. EPA, 832 F.2d 1071, 1072 (9th Cir. 1988).

76. Id. at 1076 .

77. Id. at 1079.

78. 53 Fed. Reg. 49,500 (1988).

79. See id. at 49,501 . 
issuing a court order on September $19,1988 .^{80}$

\section{ii. EPA (with Trepidation) Proposed Substituting Alternative Deadlines for Obsolete Ones}

Creatimg an FIP for the South Coast Air Basin presented EPA with a series of seemingly intractable problems. First, the Agency had to determine how to reach attaminent in the Basin. Second, it had to justify its plan through an interpretation of the Clean Air Act (despite the latter's obsolete attainment deadlines). Most troublimg of all, given the obsolete deadlimes, EPA had to publish its plans and explanations, making them available for public inspection and cominent. The fact that statutory deadlines were ignored all over the country now had to be pubhicly acknowledged and rationalized. Any realistic plan for Los Angeles would be exceptionally hard to defend, since attainment there could only be achieved well into the future-at least 20 years beyond the statutory deadline. If any plan would be hard for courts to swallow, this would be it.

EPA had laid the groundwork for its plan for the South Coast Air Basin in a policy proposal proinulgated im late 1987. In that proposal, EPA suggested that its solution to this post-attainment date puzzle would be to discern from the structure of the Act how Congress itself would have replaced the obsolete deadlines. The proposal, which was released on November 24, 1987, detailed how states should correct their remaining ozone and carbon monoxide nonattainment problems once the statutory attainment dates had passed. ${ }^{81}$ EPA hypothesized that had Congress chosen to provide for the post-deadline eventuality, it would have created additional attainment periods analogous to the three- and five-year periods required by subsections $110(\mathrm{a})(2)(\mathrm{A})$ and $110(\mathrm{e}) .^{82}$ EPA also suggested that the post-1987 planning period was analogous to the second part $D$ planning period for those states that could not demonstrate attainment for ozone or carbon monoxide by the 1982 deadline.

As we saw earhier, the first part D period (designed to ensure attainment by 1982) required plans to contain all "reasonably available control measures." measures be suppleınented by a stricter permit program for new or modi-

80. Id.

81. 52 Fed. Reg. 45,044, 45,066-67 (1987) (proposed Nov. 24, 1987). During 1986, EPA had proposed an alternative solution known as REEP ("Reasonable Extra Efforts Program"). See 52 Fed. Reg. 26,404, 26,406 (1987) (to be codified at 40 C.F.R. pts. 51 \& 52) (proposed July 14, 1987) (citing 51 Fed. Reg. 34,428 (1986)). REEP was subsequently judged an impermissible interpretation of the Act. Id. at 26,408-09.

82. 52 Fed. Reg. 45,044, 45,050 (1987); see 53 Fed. Reg. 49,494, 49,500 (1988) (to be codified at 40 C.F.R. pt. 52) (proposed Dec. 7, 1988) (EPA suggesting that Congress would have provided an additional period analogous to the three- and five-year periods of $\S 110(\mathrm{a})(2)(\mathrm{A}),(\mathrm{e}))$.

83. 42 U.S.C. $\S 7502($ b)(2) (1988) (amended 1990). 
fied stationary sources, a vehicle inspection and inaintenance program, and "other measures necessary to provide for attainment" by the end of the extension period. ${ }^{84}$ In its 1987 proposal, the Agency suggested applying these same stricter requirements to the states still not in attainment in the post-deadline period.

EPA pubhished its proposed FIP for the South Coast Basin on December 7, $1988 .{ }^{85}$ It described the particular difficulty of planning for attaininent in the Los Angeles area and evaluated three alternatives. The first, immediate attainment, was rejected as an impossibility: "residents of the area would face the destruction of daily life as they know it, and the likely prospect of mass evacuation."86 A second alternative, attainment in three to five years, was judged to be equally impracticable: "the population would effectively face a choice of resettling elsewhere, or living in alinost coinplete dependence on the governing authorities for life's basic necessities."87 The third alternative was the only one EPA conld recoinmend: a longer-term attainment plan that would " provide for attaininent as expeditiously as possible." "88

EPA acknowledged that by promulgating such a long-term plan it inight exceed its statutory authority. However, the Agency asserted that this plan was the only practical one and that, $m$ the absence of inore recent congressional action, it reflected the Agency's best efforts to achieve a result consistent with the statute's goal of clean air. EPA took no final action on its proposed FIP, probably in the hope that Congress would soon break out of its deadlock and pass amendinents, thereby ending the need for an FIP.

\section{iii. Ninth Circuit Strikes Down EPA's Deadline Substitution Policy}

Although EPA's 1988 proposed FIP for the South Coast Basin was never challenged, EPA's deadline substitution pohicy did receive judicial scrutiny when the Ninth Circuit reviewed EPA's approval of a state plan for Arizona in Delaney v. EPA. ${ }^{89}$ Delaney involved EPA's approval in 1988 of Arizona's SIP revisions regarding attainment of carbon monoxide standards in Maricopa and Pima Counties. Arizona's attainınent plan for these counties had been the subject of previous litigation. ${ }^{90}$

84. Id. $\S 7502(\mathrm{~b})(11)$.

85. 53 Fed. Reg. 49,494 (1988) (to be codified at 40 C.F.R. pt. 52) (proposed Dec. 7, 1988).

86. Id. at 49,509 .

87. Id. at 49,511 .

88. Id.

89. 898 F.2d 687, 689 (9th Cir.), cert. denied, 111 S. Ct. 556 (1990).

90. Id. In 1983, EPA conditionally approved Arizona's plans for carbon monoxide attainment for these counties; the State, however, had failed to meet EPA's conditions. Id. Arizona then applied unsuccessfully to the Agency for an extension of the attainment deadline. Id.

Despite being denied the extension, Arizona resubmitted its SIP for the counties based on the 1987 deadline. Id. EPA refnsed to approve these revisions and its decision was upheld in Arizona v. Thomas, 824 F.2d 745 (9th Cir. 1987). Delaney, 898 F.2d at 689. The Arizona district court soon 
Under a court order either to approve an SIP or to promulgate a plan of its own, EPA eventually approved the State's plan.91

The revised plan in turn became the focus of litigation in Delaney. ${ }^{92}$ In defendimg its approval of the state plan, EPA asserted that it had found the plans for the two counties adequate since they had provided for attainment within a three-year period following agency approval..$^{93}$ This three-year deadline clearly extended beyond the explicit 1982 date provided in the statute. To justify this apparent contradiction of specific statutory language, EPA argued that there was a statutory gap for nonattainment areas past the final attainment deadline and that it was reasonable to assume Congress intended these areas to have three years from the time the Agency approved their revised plans to reach attainment. ${ }^{94}$

Applying the "arbitrary and capricious" standard,95 the court struck down EPA's approval of the plan and with it EPA's deadline extension policy. It found the Act's language "clear and unambiguous" regarding the absolute deadline of $1982^{96}$ and dismissed EPA's interpretation as a mere "semantic game" to accord the state more leniency than Congress had exphicitly intended. ${ }^{97}$

Nevertheless, the awkward fact remained that the Act did not address what to do should a deadline pass or become otherwise obsolete. The Delaney court's solution was to substitute its own interpretation in place of the Agency's. It asserted that the "only reasonable interpretation" of the 1977 amendments was that "if the 1982 deadline that Congress specified is not met, the national ambient air quality standards inust be attained as soon as possible with every available control measure, includimg those that the EPA identified in its criteria for approving 1982 plans." 98 The phrase "as soon as possible with every available control measure" is a judicial creation, for it did not appear anywhere in part $D$.

The phrase suggests that the court intended that all available measures, no inatter how drastic or disruptive, be employed to ensure attaininent of the air quality standards. This, however, was not the case. Instead, all that the court required was that all measures that EPA had in the past presumed reasonably available be employed and that other

ordered EPA to promulgate FIPs for both counties unless Arizona acted swiftly to submit an adequate plan. See id. (citing McCarthy v. Thomas, 17 Envtl. L. Rep. (Envtl. L. Inst.) 21,214 (D. Ariz. 1987)).

91. 53 Fed. Reg. 30,220, 30,224, 30,329 (1988) (to be codified at 40 C.F.R. pt. 52) (proposed Aug. 10, 1988) (setting out Pima and Maricopa Counties' plans).

92. 898 F.2d at 689.

93. See id.

94. Id. at 690-91.

95. "We will not set aside the EPA's approval of a state implementation plan unless it is arbitrary, capricious, or otherwise not in accordance with law." Id. at 689.

96. Id. at 690 (citing Abramowitz v. EPA, 832 F.2d 1071, 1079 (9th Cir. 1988)).

97. Id. at 691 .

98. Id. (emphasis added). 
suggested measures not be rejected without explanation. The plan EPA had approved, and the court had struck down, contained only three transportation control measures. EPA claimed that additional control measures would not accelerate attainment. The court found EPA's claims unconvincing. It pointed out that EPA's own earlier guidance document had aimounced that eighteen pollution control measures were presuined reasonably available. ${ }^{99}$ Since the plan for these counties did not contain a "serious commitınent to many of [these] ineasures," 100 the court found it "arbitrary and capricious" for EPA to approve the plan without a demonstration of why the neglected measures were inappropriate. ${ }^{101}$

The court also suggested that EPA had done less than it could have by allowing state and county officials to reject without explanation ineasures proposed by a local planning organization and an environmental research group. The court held that since there was an obhigation to bring these areas into attainment "as soon as possible," the burden was on the State and the Agency to show why each reasonably available control measure had not been included. ${ }^{102}$ Finally, the court directed EPA to disapprove the challenged state plan and to promnlgate its own federal plan for the region within six inonths. ${ }^{103}$

By telling the Agency that it had to employ certain pollution control measures unless it could make a substantial showing that they were unnecessary, the Delaney court restrained Agency flexibility and started down the shippery slope of "hard look" review. ${ }^{104}$ Moreover, by making itself the arbiter of what measures were futile, the court assumed for itself technological and econonnic feasibility decisions best reserved for Agency discretion and flexible decisionmaking. ${ }^{105}$ In so doing, the court ignored the key principle of Chevron U.S.A., Inc. v. Natural Resources Defense

99. Id. at 692 (quoting from EPA guidance document, 44 Fed. Reg. 20,375 (1979)).

100. Id.

101. Id. Here the court seemed to directly contradict California Air Resources Board v. EPA, 774 F.2d 1437 (9th Cir. 1985), a case with analogous circumstances, which found that there was "no basis for holding, as a matter of law, that a state which has once adopted certain measures thereby commits itself to their inclusion in future plans. Such a result would discourage experimentation with pollution control measures." Id. at 1442.

102. Delaney, 898 F.2d at $691-92$. The court's holding and remedy suggest that it did not want EPA to treat the counties more lemiently than areas that met the deadline by implementing strict pollution controls. On the other hand, the opimion also suggests that the court did not wish the Agency to treat the counties more harshly than nonattainment arcas granted extensions to 1987 under $\$ 172(a)(2)$. See id.

103. Id. at 695 .

104. For information about "hard look" review, see generally WALTER GELLHORN ET AL., AdMINISTRATIVE LAW: CASES AND COMMENTS 475-503 (8th ed. 1987).

105. This contrasts sharply with the Supreme Court's rcasoning in the landmark case of Chevron U.S.A., Inc. v. Natural Resources Defense Council, 467 U.S. 837, 863-64 (1984) (stating that courts should give deferential treatment to an administrative agency's construction of the statute it administers and flexibility to an agency, allowing it to consider "the wisdom of its policy on a continuing basis"). 
Council: that it is a "basic legal error" for a court to adopt a "static judicial definition" of a statutory term once "it ha[s] decided that Congress itself ha[s] not commanded that definition."106 The court's purpose was obvious: to make EPA require additional control measures to ensure faster attainment of air quality standards.

Herein hes the paradox of Delaney. The court interprets the statute to require attainment "as soon as possible with every available control measure," yet refrains from taking that imterpretation to its logical conclusion: requiring all effective measures such as gasoline rationing and plant closures even if they are substantially disruptive. Although the court's resolution may appear Solomoneic, ${ }^{107}$ it is difficult to justify as a inatter of statutory interpretation. This is particularly true in light of the Supreme Court's decision in Union Electric Co. v. EPA, ${ }^{108}$ which held that claims of econormic and technological infeasibihty could not be asserted against an implementation plan where the statute set firm deadlines.

In short, although the Delaney court's invalidation of EPA's general pohicy was understandable at one level-a court could easily find that the Agency's substitution of deadhines went well beyond mere statutory interpretation - the grounds for its own decision were hardly more principled. The opinion's "as soon as possible" requirement was no truer to the actual statutory language than were EPA's extrapolated deadlines. The only difference between EPA's substituted deadhine policy and the Delaney court's ruling was that the former was more candid than the latter.

\section{iv. EPA Forced to Revise Its FIP for Los Angeles}

After the Delaney decision, it was clear that EPA's proposed federal plan for Califorma's South Coast Air Basim-which rested on the rationale struck down in Delaney-would not withstand judicial scrutiny. Although Congress was closer than ever to amending the Act, the Agency was still under court order to produce a legally sufficient FIP by July 31, 1990.

On September 5, 1990, EPA published a revised FIP frankly acknowledging the likely futility of its efforts im light of imminent congressional action. As it explained,

[T] he present notice of proposed rulemaking, which describes the FIP

EPA is considering for promulgation, may appear doubly inappropriate; first, because local authorities are engaged in reasonable, indeed, extraordimary efforts to deal with the air pollution problem themselves and, second, because amendments imminent to the Clean Air Act will

106. Id. at 842 .

107. See Train v. Natural Resources Defense Council, 421 U.S. 60, 73 (1975).

108. 427 U.S. 246 (1976). 
almost certainly change the nature and scope of EPA's responsibilities before EPA issues in final form the plan proposed here. ${ }^{109}$

EPA's frustration was even more acute since the proposed amendments to the Act contained provisions specially designed for the South Coast Air Basin. ${ }^{10}$ EPA promulgated the court-ordered FIP to honor its legal obligation and to "lend maximum support to the contmued development of the State plan, [which would eventually] . . . supplant the federal plan in a manner intended by the framers of the Clean Air Act."111

EPA proposed an attainment date for ozone of 2010 and for carbon monoxide of either 2000 or $2004 .{ }^{112}$ EPA explamed that these dates satisfied the Delaney holding because they "represent attainment 'as soon as possible, with every available control measure,' but without requiring absurd, impossible, or unenforceable measures." 113 Such window dressing could not disguise that these projected attainment dates hardly fulfilled the requirements of Delaney's pseudo-"plam meaning" approach to statutory deadlimes.

\section{v. A Backward Glance: EPA's 1972 Attempt to Plan for Los Angeles}

The dangers of the judicial intrusiveness presented in Delaney are especially apparent when viewed against the backdrop of EPA's earhier attempts pursuant to court order to plan for air quality attainment im Los Angeles. In 1972 the Agency had disapproved portions of California's SIP as prima facie inadequate to attam the NAAQS before the statutory deadline. ${ }^{114}$ Neither the State nor EPA, however, acted to rectify the plan's inadequacies until a federal district court finally ordered EPA to assume its statutory duty by "promulgatimg regulations setting forth an implementation plan" by January $15,1973.115$

EPA began promulgating plans that fulfilled its legal obligations but that were totally unrealistic. EPA's transportation control plan for the Los Angeles area ${ }^{116}$ included such dracoman control measures as gaso-

109. 55 Fed. Reg. $36,458,36,460$ (1990) (to be codified at 40 C.F.R. pts. 51 \& 52) (proposed Sept. 5, 1990). Indeed, the legislation passed on November 15, 1990, contains special provisions to deal with the extraordinary problems of some nonattainment areas such as Los Angeles. See 42 U.S.C. \$7511(a) (Supp. II 1990) (containing special provisions for areas with "[e]xtreine" ozone problems).

110. 55 Fed. Reg. $36,458,36,460$ (1990).

111. Id. at 36,461 .

112. Id.

113. Id.

114. 37 Fed. Reg. 10,852 (1972).

115. Riverside v. Ruckelshaus, 4 Env't Rep. Cas. (BNA) 1728, 1731 (C.D. Cal. 1972) (ordering EPA to prepare FIP to meet photochemical oxidant standard).

116. 38 Fed. Reg. 31,232 (1973) (to be codified at 40 C.F.R. pt. 52). For a fuller description and discussion of EPA's 1973 final transportation control plan for the South Coast Basin, see KRIER \& URSIN, supra note 30, at 221-34; Eli Chernow, Implementing the Clean Air Act in Los Angeles, 4 Ecology L.Q. 537 (1975); Downing \& Brady, supra note 21, at 237; John Quarles, The 
line ratioming ${ }^{117}$ of up to eighty-two percent of then-current consumption levels. ${ }^{18}$ Needless to say, such rationing was completely unacceptable to the residents and businesses of the Basin which were (and still are) vehicle-dependent. Agency officials were well aware that these proposals were likely to be unworkable. ${ }^{119}$ The Administrator himself commented, "[T] he EPA does not beheve that massive gasoline rationing is either socially acceptable or enforceable ...."120 Nonetheless, EPA steadfastly maintained that it liad "no presently available legal alternative."121

EPA's proposal created a backlash of public resentınent ${ }^{122}$ and spawned legislation designed to appease the outraged public. ${ }^{123}$ Angered by EPA's proposed plans, Congress slashed the pollution control measures available to the Agency. ${ }^{124}$ In 1976, EPA withdrew the controversial gasoline rationing provision of its plan. ${ }^{125}$ Acknowledging that the withdrawal of this portion would make California's SIP legally defective smce attainment was impossible without it, acting EPA Administrator Jolin Quarles stated, "[W] hatever benefits may be gamed from keeping a

Transportation Control Plans-Federal Regulation's Collision with Reality, 2 HARV. ENVTL. L. REV. 241, 248-50 (1978).

117. 38 Fed. Reg. $31,232,31,233$ (1973).

118. 38 Fed. Reg. 2194, 2195 (1973) (to be codified at 40 C.F.R. pt. 52) (proposed Jan. 22, 1973).

119. MeLnick, supra note 2, at 321-22. The EPA Administrator joked at a Los Angeles press conference about a proposed $82 \%$ gasoline rationing and other drastic measures: "Faced with the choice between my freedom [from court contempt orders] and your mobility, my freedom wins.' " Id.

120. 38 Fed. Reg. $31,232,31,237$ (1973).

121. Id. at 2195 . The Agency maintained that "[o]nly gasoline rationing is presently considered to be demonstrably effective to achieve compliance . . by 1977 [the deadline in effect at the time]."

Id. Moreover, EPA expressed the belief that even alternative measures were likely to be disruptive: [I]t appears that any plan that will attain the primary standard by 1977, whether it includes gasoline rationing or some other strategy to reduce VMT [vehicle miles traveled], will lead to significant economic disruptions and will certainly result in a major transformation in the life style of residents of the South Coast Air Basin.

Id. At approximately the same time, EPA released a White Paper which asserted, "Present knowledge does not permit mcaningful discussion of the problem of reducing trip frequencies or lengths without excessively impairing nobility." EPA et al., The Clcan Air Act and Transportation Control, EPA White Paper No. 400/9-74-001 (1973).

122. Quarles, supra note 116, at 249-50.

123. Id. at 250. The courts only exacerbated EPA's disconfiture. The Ninth Circuit upheld EPA's ability to ration gas under the 1970 Amendments as a legal pollution control measure, Santa Rosa v. EPA, 534 F.2d 150, 153 (9th Cir.), cert. dismissed, 429 U.S. 952, and vacated sub nom. Pacific Legal Found. v. EPA, 429 U.S. 990 (1976), though the sane circuit held that the Agency had no authority under the 1970 Amendments to sanction a state or its officials for failing to regulate the pollution-creating activities of their citizens, Brown v. EPA, 521 F.2d 827, 831 (9th Cir. 1975), vacated, 431 U.S. 99 (1977). Thus EPA was eaught between a rock and a hard place: it could promulgate extreme, unrealistic control measures but could not force the states to iniplement those measures or to design a nore realistic program themselves. See Quarles, supra note 116, at 254.

124. The ainendment of the Clcan Air Act in 1977 stated that measures in any iniplementation plan that involved gasoline rationing having "seriously disruptive and widespread economic or social effects" could be temporarily suspended by the state's governor. 42 U.S.C. $\S 7410$ (c)(4)(B) (1988) (repealed 1990).

125. 41 Fed. Reg. 45,565 (1976) (to be codified at 40 C.F.R. pt. 52). 
technically legal SIP on the books by retaining the gasoline rationing regulations are outweighed by the seriously disruptive social and economic consequences of such regulations." 126 Significantly, no one challenged this withdrawal. ${ }^{127}$

The fiasco of EPA's 1972 plan for Los Angeles amply demonstrates the pitfalls of strict statutory interpretation in the face of absurd results. Although it fulfilled its legally mandated duty by designing a draconian plan, EPA failed to ensure the realization of the statute's purpose (clean air) or of its language (attainment by the deadhine). Paradoxically, by fulfilling its duty to create a plan in accordance with statutory requirements, the Agency hampered subsequent efforts to clean the air by angering the public and Congress to such an extent that its pollution control powers were curtailed. All this did nothing to alleviate the underlying statutory problem, an unrealistic deadline. By rejecting EPA's attempts to deal sensibly with an obsolete deadline, the Delaney decision created a similar time bomb.

\section{c. The Larger Consequences of Unrealistic Statutes and Judicial Decisions}

Unrealistic deadlines entangle agencies and courts in counterproductive, no-win situations. ${ }^{128}$ Judicial decisions forcing an agency to do the impossible or telling it how to design its plans can dramatically affect an agency's internal workings. In some cases judicial review has produced a valuable second look at an agency decision, ${ }^{129}$ but in other instances, it has substantially changed agency priorities and practices for the worse. Shep Melnick explams these consequences in depth in his book Regulation and the Courts, which gives a detailed account of how judicial activisin has substantially affected EPA. ${ }^{130}$

As the discussion above illustrates, judicial decisions can also force an agency to proinulgate unenforceable or ineaningless regulations, which harm agency credibility. The backlash from EPA's gasoline rationing scheine for the South Coast Air Basin-promulgated under a court order-shows that when the public outcry becoines fierce enough, Congress will act with only short-term goals in mind: in that case, by liniting the pollution control measures available to EPA. Although this

126. Id.

127. 53 Fed. Reg. $49,494,49,498$ (1988) (to be codified at 40 C.F.R. pt. 52) (proposed Dec. 7, 1988) (discussing EPA's withdrawal of the gasoline rationing plan).

128. In its 1990 proposed FIP for the South Coast Basin, EPA made the cogent, and understandable, objection that "[g]iven the imminent prospect of the Amendments, the present task of the Agency to write a FIP under the old statute goes beyond déjà $v u$ to sheer anachronisın." 55 Fed. Reg. 36,464 (1990) (to be codified at 40 C.F.R. pts. 51 \& 52).

129. See Symposium, Administrative Law Symposium: Question and Answer with Professors Elliott, Strauss and Sunstein, 1989 DukE L.J. 551, 555.

130. MELNICK, supra note 2, passim. 
curtailment had long-term consequences for the Agency, it did not resolve the core problem of unrealistic deadlines. Instead of revising the substance of the statute and facing the realities such revision would require, Congress eviscerated the Agency's power to enforce an unrealistic statutory mandate. Needless to say, this was not a desirable result.

Legislative overruling of agency regulations also harms the agency's credibihity with pollution emitters. These emitters may become more willing to ignore unfavorable regulations in the hope that Congress will override the agency again. Regnlations themselves become hollow threats once emitters and the general public sense that EPA has neither the intention nor the ability to implement them.

When a court interferes with agency decisions in "hard look" review, it may also find that it loses the respect of agency officials, who appreciate the technical issues more completely than do the courts. Yale Law Professor Donald Elliot recounts the following example based on his personal experience:

[I]n the Vermont Yankee case, and in the Baltimore Gas and Electric case, . . . Judge Bazelon, for whom I was working, got the half life of plutomium wrong by a factor of 10 . Now, this is a quite inessential element of the case, but you can imagine this going back to the scientists at the Nuclear Regulatory Commission and their saying, "This bozo doesn't even know what the half-life of plutonium is."131

When reviewing agency action, a court finds itself in a quandary. It wishes neither to enforce statutes that require unduly harsh results nor to delve into technical subtleties; yet, it must somehow ensure that agencies do not overstep their statutory authority. Courts cannot be blamed when they rein in overeager agencies. But they can be blamed when they substitute their own implausible solutions for agency determinations in areas where agencies have greater competence and where there is no good legal justification for courts to interfere. This is where the Delaney court strayed and where future courts may tread without a clear congressional directive on how to deal with obsolete attamment deadlines.

A central aspect of the judicial role is the public elaboration of the reasoning behnid judicial determinations. ${ }^{132}$ A judicial decision reached solely on the basis of pragmatism where the issue before a court is one of statutory interpretation clearly does not fulfill this proper judicial role. For this reason, the judicial opinions in many of the easy cases were defective. Even a decision allegedly based on the "plain meaning" of the text may also violate this duty. For example, the Delaney court argued that it was implementing the "plain meaning" of the deadlines, but it neither instituted the strictest possible pollution control measures nor gave any principled reason for choosing the measures it deemed

131. Symposium, supra note 129 , at 559 .

132. HART \& SACKS, supra note 66 , at 4-5. 
"required" by the statute. A truly acceptable solution to the attainment deadline dilemma must permit courts to adhere to proper judicial decisionmaking procedures by allowing them to act consistently with both statutory language and the statute's underlying purpose. Such a solution is proposed in the next Part of this Comment.

II

The Best Practical Solution: Employ Severability Clauses

As the previous discussion illustrates, the core problem with attainment deadlines is their tendency to becoine obsolete. A logical solution to this problem would be for Congress to include only realistic deadhines in its environmental statutes. However, this solution is unlikely to be inplemented as long as Congress believes that deinanding deadlines will force teclinological change to occur at a faster pace. Absent a change of heart in Congress, the most attractive solution to obsolete deadlines is to reinove them froin the statute on a case-by-case basis. Courts and the Agency have attempted this on occasion, but in many cases they have been unable to find a principled legal justification for using this approach. The obvious question is whether there is a legally defensible way to reinove obsolete deadlines from a statute. This Part suggests that a common legislative device, the severability clause, could provide just such a legally justifiable way to eliminate obsolete deadlines.

\section{A. A Problem for the Court or the Agency?}

Before entering into our discussion of severabihty, we will pause to consider why Chevron U.S.A., Inc. v. Natural Resources Defense Council ${ }^{133}$ fails to solve the dilemma for us. In Chevron, the basic issue was whether the implementing agency or a court was the appropriate body to define a key statutory terin (in that case, "stationary source"). ${ }^{134}$ When Congress enacted the statute im question, it had neither specifically defined the key term nor designated who was to interpret it. The Court held that in such a case, where Congress has not expressed a clear intent,

the court does not simply impose its own construction on the statute, as would be necessary in the absence of an adininistrative interpretation. Rather, if the statute is silent or ambiguous with respect to the specific issue, the question for the court is whether the agency's answer is based on a permissible construction of the statute.

... If Congress has explicitly left a gap for the agency to fill, there is an express delegation of authority to the agency to elucidate a specific provision of the statute by regulation. Such legislative regulations are given controlling weight unless they are arbitrary, capricious, or mani-

133. 467 U.S. 837 (1984).

134. Id. at $842-44$. 
festly contrary to the statute. Sometimes the legislative delegation to an agency on a particular question is implicit rather than explicit. In such a case, a court may not substitute its own construction of a statutory provision for a reasonable interpretation made by the administrator of an agency. ${ }^{135}$

Thus where Congress has not spoken, an agency may make policy choices "within a gap left open by Congress."136 The court's role is merely to determine whether this policy or interpretation is reasonable. ${ }^{137}$

Unlike the statutory term at issue in Chevron, the deadlines involved in our dilemma are specific by their very nature. These deadlines appear to leave no room for agency interpretation. Indeed, this is what the Delaney court concluded: Chevron's deferential approach was inappropriate given the specificity and clarity of the statutory terms at issue. ${ }^{138}$ It follows that where a statutory term is clear and specific, it is a court's province to ensure its enforcement. Our problem arises because enforceinent of a specific statutory term, the attaininent deadline, would produce absurd results.

\section{B. How the Solution Works}

A severability clause is a cominon statutory feature. It is essentially a savings provision ensuring that an entire statute does not collapse when one of its provisions is invalidated. It permits the reinoval, or severance, of the invalidated provision, while the rest of the statute remains in force as governing law. The 1977 Clean Air Act contained a typical severability clause: "If any provision of this chapter, or the application of any provision of this chapter to any person or circunstance, is held invalid, the application of such provision to other persons or circumstances, and the remainder of this chapter shall not be affected thereby."139

Again taking the 1977 Clean Air Act as a focus, this Part argues that judicious use of this clause might have helped the Agency and courts escape the attainment deadhine dilemma described in Part $I$. The clause itself suggests a two-pronged inquiry: first, whether a deadline is a provision that a court can invalidate; and second, whether such a finding of invalidity triggers application of the severability clause, preserving the legal effectiveness of the reinainder of the statute.

135. Id. at 843-44 (footnotes omitted).

136. See id. at 866 .

137. See id. at 865-66.

138. Delaney v. EPA, 898 F.2d 687, 689-91 (9th Cir.), cert. denied, 111 S. Ct. 556 (1990).

139. 42 U.S.C. $\S 7615$ (1988). 


\section{A Court Could Plausibly Find the Deadlines Either Absurd or Impossible and Thus Invalid}

Once the attainment deadlines have passed, a court contemplating attainment planning for a "hard" case (a severely out-of-attainment area) would have hittle difficulty in finding the deadlines obsolete and thus invalid. When faced with enforcing an obsolete attainment deadline, a court has two options: immediate attainment (the closest thing to the original date that the court can require) or longer-term attainment. With respect to the latter option, Delaney indicates that as long as the deadlines remain in the statute, courts will be reluctant to permit long-range attainment planning, because to do so would appear to be straying far from the clear statutory language of the deadlines into the realm of legislative policyınaking.

A court is therefore left with one option as long as the deadlines stand: immediate attainment. As we lhave seen, courts may be able to order immediate or at least swift attainment in some easy cases, those where attainment may be achieved quickly through impleinentation of existing measures or measures that are feasible without substantial disruption. However, ordering immediate attainment in the harder cases is lighly unrealistic. As we saw in the case of the Los Angeles region, had EPA ordered immediate attainment, "the residents of the area would [have faced] . . . the destruction of daily life as they know it, and the likely prospect of mass evacuation."140

It is a coinmonly accepted primciple that courts should avoid interpretations of a statute that produce absurd results. ${ }^{141}$ Thus, in the hard cases-where immediate attainment would produce absurd results-a court would mevitably conclude that the deadlines must be invalidated.

\section{Under the Two-Part Chadha Test, the Deadlines May Be Severed from the Act}

The second question is whether, when a court finds a deadline obsolete and its enforcement absurd, it may sever the deadline froin the rest of the statute. The Supreme Court spelled out the principles governing severability in Champlin Refining Co. v. Corporation Commission, ${ }^{142}$ United

140. 53 Fed. Reg. 49,494 49,509 (1988) (to be codified at 40 C.F.R. pt. 52) (proposed Dec. 7 , 1988); see supra text accompanying notes $85-88$.

141. See, e.g., Griffin v. Oceanic Contractors, Inc., 458 U.S. 564, 575 (1982) (stating that "absurd results are to be avoided if alternative interpretations consistent with the legislative purpose are available"); United States v. American Trucking Ass'ns, 310 U.S. 534, 543 (1940) ("When that [plain] meaning has led to absurd or futile results, however, this Court has looked beyond the words to the purpose of the act.") (footnote omitted).

142. 286 U.S. $210,234-35$ (1932) (dealing in part with the severability of provisions). 
States v. Jackson, ${ }^{143}$ and, most recently, in INS v. Chadha. ${ }^{144}$ A severability clause in the statute need not be present in order to sever a statutory provision. ${ }^{145}$ However, when Congress places a severability clause in an act, it creates a rebuttable presumption that each provision of the act is severable. ${ }^{146}$

In Chadha, the Court promulgated a two-part inquiry governing the severability of a particular provision. A court must ask first whether Congress intended the "validity of the Act as a whole, or of any part of the Act," to rest upon the validity of the provision to be severed. ${ }^{147}$ If so, severance is not permitted. If not, the court asks a second question, whether "what remains after severance is "fully operative as a law," "148 If it is, severance is permitted. As noted above, the presence of a severability clause in a statute creates a rebuttable presumption that a provision held invalid on constitutional or other grounds ${ }^{149}$ will be severable. When examining a potentially severable provision, a court inust look to the legislative history to determine whether there is sufficient evidence regarding the provision to rebut this presumption.

In Chadha, the severability provision given effect by the Supreme Court was almost identical to the one in the 1977 Clean Air Act. ${ }^{150}$ The Chadha Court found the language of the severability clause "unambiguous" and concluded that "Congress could not have more plainly authorized the [severability] presumption."151 Moreover, it found nothing in

143. 390 U.S. 570, 585 (1968) (applying the Champlin Refining Co. test to determine that the entirety of the Federal Kidnaping Act was not invalidated when its capital punishment clause was found unconstitutional).

144. 462 U.S. $919,931-35$ (1983).

145. Jackson, 390 U.S. at 585 n.27.

146. See Alaska Airlines v. Brock, 480 U.S. 678, 684-86 (1987); Chadha, 462 U.S. at 931; Jackson, 390 U.S. at 585 n.27; Champlin Ref. Co., 286 U.S. at 235.

147. Chadha, 462 U.S. at 932.

148. Id. at 934 (quoting Champlin Ref. Co., 286 U.S. at 234).

149. Courts have generally severed unconstitutional clauses from statutes. See, e.g., Alaska Airlines, 480 U.S. at 684; Regan v. Time, Inc., 468 U.S. 641, 653 (1984) ("Whether an unconstitutional provision is severable ... is largely a question of legislative intent, but the presumption is in favor of severability.") (plurality opinion); Chadha, 462 U.S. at 934; Jackson, 390 U.S. at 585-91; Reyes v. INS, 910 F.2d 611, 613-14 (9th Cir. 1990) (pointing out that the absence of a severability clause in executive order granting naturalization to military service personnel suggests that all elements of order are essential and that geographic and teinporal restrictions may not be severed). However, unconstitutionality is not the only reason an invalid clause or provision may be severed from a statute.

One commentator points out that the real issue is not one of actual but of hypothetical legislative intent: "[S] everability is a question of hypothetical legislative intent: it asks, if the legislature had known that part of its chosen statutory approach would be invalidated, what statutory disposition would it have wanted?" Glenn C. Smith, From Unnecessary Surgery to Plastic Surgery: $A$ New Approach to the Legislative Veto Severability Cases, 24 HARV. J. ON LEG1s. 397, 402 (1987) (footnote omitted).

150. In Chadha, the provision at issue was $\S 244(\mathrm{c})(2)$ of the Immigration and Nationality Act. See 462 U.S. at 931.

151. Id. at 932 . 
the legislative history sufficient to rebut the presumption in favor of severability. ${ }^{152}$

As was the case in Chadha, there is nothing in the legislative history of the 1977 Clean Air Act sufficient to defeat the presumption that the deadline provisions are severable. Although the legislators who enacted the Act viewed the deadlines as important components of the statute, nothing indicates that they viewed them as such an essential part of the statute that it would fall in their absence. Indeed, some have suggested that Congress did not imtend or expect that the deadlines, which some members admitted were unrealistic, would be attained in every circumstance. ${ }^{153}$ Given this, it is unlikely that a court would have found that the obsolete deadlines were so crucial to the 1977 Act that "the Legislature would not have enacted those provisions which are within its power, independently of [the deadlines]."154 A court would have presumed that Congress meant for the deadline provisions to be severable. ${ }^{155}$

The presumption in favor of severability is buttressed by evidence that the 1977 Act would operate without the outdated deadlines "in a manner consistent with the intent of Congress." 156 Congress' stated purposes for requiring air quality and emission limitations were:

(1) to protect and enhance the quality of the Nation's air resources so as to promote the public health and welfare and the productive capacity of its population;

(2) to initiate and accelerate a national research and development program to achieve the prevention and control of air pollution;

152. Id. at 934 .

153. 53 Fed. Reg. 49,494, 49,501-08 (1988). But cf. Reed, supra note 9, at 10,026 \& n.54. Reed suggests that City of Seabrook v. EPA, 659 F.2d. 1349 (5th Cir. Unit A Oct. 1981), cert. denied, 459 U.S. 822 (1982), stands for the proposition that the 1982 attainnent deadline is at the "heart" of the 1977 Amendinents. Reed, supra note 9, at 10,026 n.54. I read Seabrook differently. There, the court treats the language of $\S 172(a)(1)$, which includes the phrase "as expeditiously as practicable" as well as the attainment date, as "the heart" of the 1977 Amendments. See Seabrook, 659 F.2d at 1357. Since courts have found that the "as expeditiously as practicable" language has force even without the deadline, e.g., American Lung Ass'n v. Kean, 871 F.2d 319, 328 (3d Cir. 1989), and there is a presuniption that an invalid provision niay be severable, it is unlikely that "the heart" of the 1977 Amendments would be cut out nerely because the deadline provisions are invalidated on the grounds of inipossibility.

154. Champlin Ref. Co., 286 U.S. at 234; accord cases cited supra notes 143-44, 149.

155. See generally OfFice of Legal Policy, U.S. DeP'T of Justice, Using aNd Misusing Legislative History: A Re-Evaluation of the Status of Legislative History iN STATUTORY INTERPRETATION (1989) (report to the Attorney General). This report outlines the basic problein of favoring legislative history over actual statutory language to discern congressional intent: "An approach to statutory interpretation that looks to the intended meaning at the expense of the incaning the statutory words actually convey is inore likely to draw out precisely tlose inproper inotives and desires that bicameral enactinent of the statute helped to push into the background." Id. at 30; see also Jonathan R. Macey, Promoting Public-Regarding Legislation Through Statutory Interpretation: An Interest Group Model, 86 CoLUM. L. REV. 223, passim (1986) (advising that courts rely on traditional methods of statutory construction instead of on inethods that recognize sonie legislation as a contract between Congress and narrow interest groups).

156. Alaska Airlines v. Brock, 480 U.S. 678, 685 (1987). 
(3) to provide technical and financial assistance to State and local governments ...; and

(4) to encourage and assist the development and operation of regional air pollution control programs. ${ }^{157}$

As detailed below, abiding by the language left after the deadlines are severed in part $\mathrm{D}$ would further these stated objectives.

The second inquiry under Chadha is whether the statute can function effectively without the invalid provision. In Jackson, the Supreme Court rehed on a common sense analysis to assess the viability of severing a provision from a statute. ${ }^{158}$ Jackson dictates that severability is permissible only when removal of the provision "in no way alters the substantive reach of the statute and leaves completely unchanged its basic operation," 159 and when the remaiming statutory language would further "the law's fundamental objective."160 In Chadha, the Court found that after severance the statute would still be "fully operative" "161 and would provide "workable administrative machinery."162 As a consequence, severance was permissible.

Applying Jackson's common sense analysis to the 1977 Clean Air Act, we find that reinoving the deadline provisions from part $\mathrm{D}$ would leave the Act's basic requireinents for nonattainment areas intact. States would still be obliged to plan for attainment "as expeditiously as practicable,"163 to provide for the implementation of $\mathrm{RACT},{ }^{164}$ to maintain new-source permitting programs, and to enforce necessary emission limitations. In addition, the federal-state partnership would not be significantly altered by the removal of the deadlines. States would still need to proinulgate SIPs, while EPA would still need to approve or disapprove state plans (and in some cases design FIPs). Thus, the division of powers established by the Act would remain undisturbed.

Excising the attainment deadhines from section 172(a) of the 1977 Clean Air Act would leave the following language:

(1) The provisions of an apphicable implementation plan for a State relating to attainment of national ambient air quality standards in any

157. 42 U.S.C. $\$ 7401(\mathrm{~b})$ (1988) (amended 1990) (emphasis added).

158. 390 U.S. $570,586-89$ (1968).

159. Id. at 586.

160. Id. at 591 n.36.

161. INS v. Chadha, 462 U.S. 919, 934 (1983) (applying language from Champlin Refining Co.

v. Corporation Commission, 286 U.S. 210, 234 (1932)).

162. Id. at 934.

163. See, e.g., American Lung Ass'n v. Kean, 18 Envtl. L. Rep. (Envtl. L. Inst.) 20,317 (D.N.J. 1987), aff'd, 871 F.2d 319 (3d Cir. 1989).

164. See, e.g., Michigan v. Thomas, 805 F.2d 176, 180 (6th Cir. 1986) (affirming EPA's definition of RACT, which was " the lowest emission limitation that a particular source is'capable of meeting by the application of control technology that is reasonably available considering technological and economic feasibility' "); Bethlehem Steel v. EPA, 782 F.2d 645, 651 (7th Cir. 1986) (stating that the RACT requirements may not be dropped merely because the controls applicable to nonattainment areas expire). 
nonattainment area which are required by section $7410(a)(2)(I)$ of this title as a precondition for the construction or modification of any major stationary source in any such area after July 1, 1979, shall provide for attainment as expeditiously as practicable.

(2) In the case of the national primary ambient air quality standard for photochemical oxidants or carbon monoxide (or both) if the State demonstrates to the satisfaction of the Administrator (on or before the time required for the submission of such plan) that such attainment is not possible in an area with respect to either or both of such pollutants despite the implementation of all reasonably available measures by December 31, 1982, such provisions shall provide for the attainment of the national primary standard for the pollutant (or pollutants) with respect to which such demonstration is made, as expeditiously as practicable.

This revised version would also contain, virtually unaltered, the hist of requisite provisions for part $D$ plans found in section 172(b). The EPA Administrator would still be required to judge whether RACT was adequate to ensure attainment "as expeditiously as practicable." If she found RACT to be insufficient, she could still estabhsh a permit program governing the construction or nodification of inajor emitting facilities, promulgate a specific schedule for implementation of a vehicle emission control prograni, or impose other ineasures necessary to provide for attainment. $^{165}$

Environmental activists need not be concerned that the remaining language is too nebulous to be enforceable absent the deadlimes. History has shown that key statutory terms have discernable meanings independent from the deadline requirements. One primie exainple is the interpretation of "reasonably available control technology." Since 1976, EPA has defined RACT as " the lowest emission himitation that a particular source is capable of meetimg by the apphication of control technology that is reasonably available, considering technological and econoinic feasibility." "166 Although RACT has had the same definition since 1976, its specific requirements have not stayed the same. Indeed, as technology has advanced, EPA has upgraded RACT requirements. For example, im Michigan v. Thomas, EPA informed state officials preparing Michigan's implementation plan that:

"Most of the industrial fugitive dust regulations around the country that have been approved by the Agency have followed the example of RACTbased fugitive dust rule provided by USEPA in Appendix B of 40 CFR Part 51. It now appears that this example is no longer useful as a model

165. See 42 U.S.C. $\$ 7502$ (b)(11)(B)-(C) (1988) (amended 1990).

166. See, e.g., Thomas, 805 F.2d at 180 (citing memorandum by Roger Strelow, Assistant Administrator for Air and Waste Management). But see Union Elec. Co. v. EPA, 427 U.S. 246, 265 \& n.14 (1976) (holding that the EPA Administrator may not consider economic and technological infeasiblity when evaluating SIPs, "since offending sources always have the option of shutting down"). 
RACT rule, because increased knowledge of the subject has pointed out the need for inore specificity than this guideline contains."167

The requirement that all reasonably available control technology be employed proved equally definite and stringent after the expiration of the attainment dates. In Bethlehem Steel Corp. v. EPA, ${ }^{168}$ the Seventh Circuit, $m$ an opinion written by Judge Posner, used the definition of RACT to evaluate Indiana coke oven door regulations, finding it sufficiently specific to be enforced without an attainment deadline. ${ }^{169}$

In addition to the RACT requirement, the remaining language of part D specifies that attainment must be achieved "as expeditiously as practicable." In American Lung Association v. Kean, ${ }^{170}$ the Third Circuit upheld a district court post-attainment date scheduhing order that had been drawn up on the basis of the "as expeditiously as practicable" requirement. ${ }^{171}$ The same court also employed this standard when it evaluated the degree to which econoinic constraints should be considered in the practicability factor. ${ }^{172}$ It seems obvious that there are sufficient guidelines within the statute for the remaining provisions to be "fully operative" without the deadlines.

One iniportant objection that might be raised is that the two requirements of part D-adoption of RACT and attamnent "as expeditiously as practicable"-are meant to be interpreted in conjunction with the applicable time frame. According to this view, the statutory phrasing"[a]s expeditiously as practicable ... but ... not later than Deceinber 31, 1982" - mdicates that the date is meant to inform the meaning of the term "expeditiously." This argument lias some merit; however, the fact remams that neither the Agency nor the courts have used the statutory deadlines this strictly to set the pace of cliange. ${ }^{173}$ Instead, at the agency level, officials liave exannined what was currently feasible (botli technically and economically) and what was projected to be feasible, and used this information to enact specific RACT and "as expeditiously as practicable" requirements. ${ }^{174}$

Anotlier objection imglit be tliat absent the statutory deadlines, the Act would lose its force because industry would no longer have the

167. Thomas, 805 F.2d at 180 (quoting Letter froin EPA Region V Adininistrator to Chief of Air Quality Division, Michigan Department of Natural Resources).

168. 782 F.2d 645 (7th Cir. 1986).

169. Judge Posner, however, suggests that economic feasibility should be taken into account as well as RACT. Id. at 653. Apparently, he was unaware that EPA's definition of RACT already contained a consideration of economic feasibility. See, e.g., 42 U.S.C. $\S 7408(b)(1)$ (1988) ("[I]nformation shall include data relating to the cost of installation and operation . ...").

170. 871 F.2d 319 (3d Cir. 1989).

171. Id. at 327-30.

172. Id.

173. See, e.g., Delaney v. EPA, 898 F.2d 687 (9th Cir.) (a hard ease), cert. denied, 111 S. Ct. 556 (1990); Bethlehem Steel v. EPA, 782 F.2d 645 (7th Cir. 1986) (an easy ease).

174. See supra text accompanying notes 62-68, 89-102. 
threat of being shut down if attainment is not reached by deadline. This criticism is well taken. However, given that severance of deadhines on a case-by-case basis will only be employed as a teinporary solution-to be used until Congress amends the statute-the absence of this threat is probably less significant than it would be in an original congressional enactinent.

Moreover, it is important to realize that even with the deadlines in place, large-scale industrial shutdowns have not occurred. Although soine judges argued strenuously that deadlines must be observed, none actually enforced deadlines in the hard cases. ${ }^{175}$ In Union Electric Co. $v$. $E P A$, the Supreine Court ruled that the statute's deadlines were immutable ${ }^{176}$ and that no plan would be "infeasible," since offending polluters could be shut down. ${ }^{177}$ Despite this strong command, a majority of lower courts have followed the praginatism and reasoning of Justice Powell's concurring opimion, ${ }^{178}$ which pointed out that "the shutdown of an urban area's electrical service could have an even more serious impact on the health of the public than that created by a decline in ambient air quahity."179 Justice Powell added, "I beheve that Congress, if fully aware of this Draconian possibility, would strike a different balance."180

Moreover, the inajority in Union Electric was not confronted with so drastic an obstacle as the air quality problems in Los Angeles. Strict implementation of the statutory language in Union Electric involved no niore than the closure of three electric generating plants. ${ }^{181}$ Although closure of the plants would have had substantial impact on St. Louis, which received power froin the plants, ${ }^{182}$ it would hardly have been comparable to ordering the evacuation of one of the world's largest metropolitan areas. Were the latter possibility ever to come before the Court, it is hard to inagine the Court requiring so drastic a measure, even if the language of the statute appeared to require it. ${ }^{183}$ The Court would undoubtedly strike the more moderate balance Justice Powell suggested.

175. See, e.g., Delaney, 898 F.2d 687 passim (directing EPA to disapprove counties' plans and to promulgate federal inplementation plans despite interpreting the 1977 Amendinents to require attainment "as soon as possible" for areas not ineeting the 1982 attaininent deadline); see also supra text accompanying notes 89-102.

176. 427 U.S. $246,258-60$ (1976).

177. Id. at $265 \mathrm{n} .14$.

178. E.g., Delaney, 898 F.2d 687; American Lung Ass'n v. Kean, 18 Envtl. L. Rep. (Envtl. L. Inst.) 20,317 (D.N.J. 1987) (directing states with nonattaininent probleins to act "as expeditiously as practicable" rather than ordering the immediate shutdown of emitters), aff'd, 871 F.2d 319 (3d Cir. 1989).

179. Union Elec., 427 U.S. at 272 (Powell, J., concurring).

180. Id.

181. 427 U.S. at 252.

182. Id. at 270 (Powell, J., concurring).

183. See supra notes $140-41$ and accompanying text. 


\section{Judicial Review Would Be Unchanged}

If the severability approach were adopted and the obsolete deadlines were severed from the remainder of part D, states and the Agency would be expected to abide by part D's remaining requirements. ${ }^{184}$ Judicial review of final agency actions would then proceed on routine reasonableness grounds, limitimg judicial imquiry of agency statutory construction to whether the interpretation is sufficiently reasonable. ${ }^{185}$ Although less strict than some other standards, reasonableness review does have teeth. ${ }^{186}$ For example, courts invalidated agency interpretations on reasonableness grounds prior to the passing of attainment dates in a number of landmark decisions. ${ }^{187}$ These cases illustrate that courts can play a crucial role in interpreting an environmental statute, while refraining from inaking pohicy outside the statute's dictates.

In one early case, International Harvester Co. v. Ruckelshaus, ${ }^{188}$ the D.C. Circuit applied the reasonableness requirement and found that the technology required by the Agency did not meet the "reasonably attainable" standard because the technology was not available: "We think the

184. See, e.g., Bethlehem Steel v. EPA, 782 F.2d 645, 651 (7th Cir. 1986); cf. American Lung Ass'n v. Kcan, 18 Envtl. L. Rep. (Envtl. L. Inst.) 20,317, 20,320 (D.N.J. 1987) (ordering the implementation of a new timetable but leaving substantive standards intact), aff'd, 871 F.2d 319 (3d Cir. 1989).

185. Under the Adminstrative Procedure Act, judges must uphold agency action unless it is "arbitrary, capricious, an abuse of discretion, or otherwise not in accordance with law." 5 U.S.C. $\S 706(2)(A)$ (1988). Where statutory interpretation is concerned, this has been effectively translated into "reasonableness" review. See Chevron U.S.A., Inc. v. Natural Resources Defense Council, 467 U.S. 837, 844-45, 866 (1984); Train v. Natural Resources Defense Council, 421 U.S. 60, 87 (1975). But of. City of Seabrook v. EPA, 659 F.2d 1349, 1356 (5th Cir. Unit A Oct. 1981) ("The issue, however, is not whether petitioners' interpretation is reasonable, but whether the EPA's interpretation is 'plainly unreasonable." ") (quoting Lead Indus. Ass'n, Inc. v. EPA, 647 F.2d 1130, 1147 (D.C. Cir.), cert. denied, 449 U.S. 1042 (1980)), cert. denied, 459 U.S. 822 (1982).

An agency's factual determinations are reviewed under the Administrative Procedure Act's "arbitrary or capricious" rubric. See, e.g., id. at 1360. For exaunple, Michigan v. Thomas, a typical review case, suggested that courts should reject only those agency constructions that run counter to clear congressional intent. 805 F.2d 176, 183 (6th Cir. 1986). The Thomas court was not willing to have courts impose their own construction of the statute. Instead, the court felt that the proper judicial role was to conduct a narrow inquiry into whether the agency's construction was "sufficiently reasonable." Id.

186. Cf. Motor Vehicle Mfrs. Ass'n v. State Farm Mut. Auto. Ins. Co., 463 U.S. 29, 48-49 (1983) (taking an aggressive approach and rejecting an agency interpretation because it failed to demonstrate why the stricter alternative would not be justified instead of the laxer rule).

187. Abramowitz v. EPA, 832 F.2d 1071, 1078 (9th Cir. 1988) (concluding that, since the statute requires EPA to determine whether the SIP will provide for attainment, the Agency could not approve ozone and carbon inonoxide control ineasures without requiring a demonstration of attainment by the deadline); Lead Indus. Ass'n, Inc. v. EPA, 647 F.2d 1130, 1150 (D.C. Cir.) (establishing that EPA could not consider economic cost factors in standard-setting), cert. denied, 449 U.S. 1042 (1980); Natural Resources Defense Council v. EPA, 475 F.2d 968, 970 (D.C. Cir. 1973) (overturning EPA's decision to give states more time to produce transportation control plans); cf. Union Elec. Co. v. EPA, 427 U.S. 246, 256-60 (1976) (stating that technical infeasibility of pollution controls is not admissible as a basis for the Administrator's rejection of a plan or for a court's overturning an approved plan).

188. 478 F.2d 615 (D.C. Cir. 1973). 
vehicle inanufacturers establislied by a preponderance of the evidence, in the record before us, that technology was not available [as the Agency claimed], within the ineaning of the Act." 189 The court stated that in order for it to evaluate the reasonableness and rehability of the Administrator's conclusions with regard to "reasonably attainable" technology, the Administrator inust bear the burden of coming forward with pertiment information that the technology was available, as he had claimed it was here. ${ }^{190}$ This case and others like it illustrate the large degree of control that courts exercise over how the Agency interprets statutory requirements. Nothing in the severance of the deadline provisions would substantially alter the nature of this judicial review.

\section{The Advantages of the Severability Solution}

It is axiomatic that statutory language is determinative where there is a question concerning the interpretation or application of a statute to a particular set of circumstances. However, in determining what was required in the post-attainment deadline setting, courts and the Agency were unable to find a provision in the 1977 Clean Air Act that covered the situation. ${ }^{191}$ Although the statute did not address the problem directly, Congress had im fact provided a solution to the dilemma by including a severabihty clause in the statute. Making use of this clause to solve the problem would have been far better than einploymg the "creative" solutions that were actually endorsed by the courts and EPA.

The severance solution would not have given EPA any greater flexibility or authority than that delegated in the statute. In planning for attainment after the deadlines passed, the Agency would still have been bound by the remaining language in the statute and its actions would have been subject to judicial review. In contrast, the deadline substitution policy proposed by EPA im its 1987 policy statement ${ }^{192}$ in effect gave the Agency a role that the statute itself did not appear to permit. Likewise, judicial attempts to infuse ineaning into obsolete statutory language, as im Delaney, are equally unsatisfactory and unprimcipled.

For a judicial solution to be acceptable, it inust produce a result cominensurate with the statute's overall purpose ${ }^{193}$ and rest on articulated principles that may be apphed to subsequent cases. ${ }^{194}$ The severance solution satisfies both of these criteria. First, it facilitates the Act's purpose because it permits the Agency to plan for attainment of the air

189. Id. at 648 .

190. Id. at 643 .

191. See supra Sections I.B.3.b.ii-iv.

192. 52 Fed. Reg. 45,044, 45,065 (1987); see supra text accompanying notes 81-85.

193. See Holy Trinity Church v. United States, 143 U.S. 457, 459 (1892) ("It is a familiar rule, that a thing may be within the letter of the statute and yet not within the statute, because not within its spirit, nor within the intention of its makers.").

194. HART \& SACKS, supra note 66, at 4-5. 
quality standards. Second, it is based upon easily articulated, traditional understandings of statutory interpretation.

A principled judicial opinion consistent with the 1977 Clean Air Act's purpose would have cured the defects of Delaney and the "easy case" opinions. Unlike Delaney - which purported to follow the statute's plain nieaning yet reached a result at odds with the Act's plain command-or the decisions in the easy cases, which were justified almost entirely in pragmatic terms, the severance alternative is based on a permissible interpretation of the statute itself.

One potential objection to the severability proposal is that it involves the Agency and the court in what appear to be essentially legislative decisions. The arguinent is that Congress did not anticipate such a use of the severabihity clause, while it did intend its deadlines to be absolute; thus, using the former to reniove the latter amounts to an inipermissible, quasi-legislative amendinent of the statute. Although superficially appealing, this criticisin fails because the apphication of an existing severability clause is not analogous to the amendnient of a statute. The difference between judicial and legislative decisions is that judicial decisions are circuniscribed by the dictates of precedent and law; legislative ones, by contrast, involve great autonoiny and flexibility. A judge deciding to apply a statute's severability clause would be conifortable in the knowledge that she is acting $\mathrm{m}$ accordance with the dictates of a statute, rather than acting as a quasi-legislature.

Moreover, a great strength of the severability approacl is that it leaves to the court's discretion the determination of when to use a severability clause. Although the presence of a severabihity clause creates the presumption of a hypothetical legislative intent favoring its use, this does not inean that a court has to use it if it feels to do so would be inappropriate or if it beheves that keepmg the obsolete deadlines serves sonie useful purpose. Indeed, as eniphasized throughout, severance will only be appropriate where a court determines that absurd results will follow if the obsolete deadlines are enforced.

Another benefit of the proposed solution is, as we saw earlier, the retention of the part D requirenients,' RACT and "as expeditiously as practicable." The interpreters and followers of these requirenients would know what is required and on what basis new regulations would be formed, lending contniuity and predictability to the enforcenient process.

Unlike the solution advanced ni Delaney, which conteniplated courts imposing specific nonstatutory requirenients, severing the obsolete deadlines would have permitted the Agency to experiment with pollution control requirements so long as it impleniented part $\mathbf{D}$. This flexibility to alter and tighten requirenients would have conformed to the congressional intent that the 1977 Clean Air Act be a technology-forcing statute.

Since the severability solution has so inany advantages, one night 
wonder why the courts have not resorted to it in dealing with the attainment deadhine dilemmas created by the 1977 Act. Unfortunately, it is difficult for the researcher to provide a convincing answer to this question. There is no evidence available that courts have even considered the severability approach, and no source reveals why courts have eschewed this particular path. Indeed, it is seldom that judicial opinions themselves discuss rejected alternatives. One might surmise either that the severability clause is so commonplace in federal legislation that it did not capture the attention of the courts and the Agency, or that courts were unwilling to employ the clause without explicit congressional authorization. If the latter were the case, however, the courts' misgivings were unwarranted, since a legislature need not have anticipated a specific use of a severability clause for a court to use it that way.

\section{The Role of Congress: Severability and Aspirational Statutes}

It seems that the inost effective way for Congress to proinote the use of severability clauses would be either to draw attention to these clauses by explicitly recommending their use should attaimment deadlines becoine obsolete, or to imclude specifically tailored severability provisions in statutes. Such congressional action would require legislators to acknowledge the prospect that the deallines would becoine obsolete before amendinent occurs. After all, the deadlines would ouly be severed when the statute's substantive provisions had failed to achieve attainment within the statutory deadlines. Providing for this eventuality is unlikely to be politically costly to meinbers of Congress. It may even prove quite popular among thein because it would give the Agency and courts adequate flexibility to work within the statute rather than forcing them to promulgate absurd regulations and decisions, which ultimately redound to the discredit of the legislature. In fact, Congress inay even have a duty to provide for severability whenever it enacts technology-forcing statutes, given the high likelihood that certain statutory goals will not be met and that amendment often occurs too late to save statutory deadhines froin being obsolete.

Just as severability clauses are particularly appropriate in technology-forcing statutes, they are also useful in "aspirational statutes." Aspirational or symbolic statutes are laws that express goals that we wish we could achieve, rather than what we can realistically achieve. Unlike other laws, aspirational statutes establish impossible goals and lack mechanisms for adjusting these goals to the practical necessities of implementation. The 1977 Clean Air Act is a good example of an aspirational statute, because its health-based air quality standards (the NAAQS) permit no consideration of the econornic and societal costs of clean air.

Numerous scholars have criticized the statutory draftsmanship of 
aspirational statutes. ${ }^{195}$ Nevertheless, it appears unlikely that Congress will abandon aspirational-type statutes in the near future. Elected legislators will always be wary of inaking unpopular decisions or appearing to cave into industry pressure where the public's health or safety is at stake. ${ }^{196}$ By comparison, agency officials are less concerned with electoral politics. In addition, their specialized expertise enables thein to appreciate the practical implications of agency regulations and to assess (without the pressures of legislative politics) exactly what costs polluters will bear. ${ }^{197}$ Thus, where compromises need to be made, it may be more realistic to leave thein to agency officials than to legislators.

Since Congress.will continue to dodge the hard choices involved in planning for a cleaner environment, it should at least desigu its statutes so as to give the impleinenting agency the authority to adapt Congress' aspirational commands when these commands becoine so obsolete that the results of their enforcement are absurd. ${ }^{198}$ By including a severability clause in aspirational and technology-forcing environinental statutes, Congress would ensure that the impleinenting agency can plan for postattainment date achievement of the statutory goal when the agency determines that attamment by the statutory deadhne is impossible. ${ }^{199}$ It is important to note that the deadline would remain in force as binding law until the agency or a court makes a determination that the deadline must be severed from the statute. Thus, severance of deadlines in the 1977 Clean Air Act would ouly have been appropriate for regions with the most extreme environmental deterioration-regions that could not meet the deadline (achieve attamment immediately after the deadline) except by imposing absurdly high costs.

195. Dwyer, supra note 60, at 245-46, 249-50.

196. See Lloyd N. Cutler \& David R. Johnson, Regulation and the Political Process, 84 YALE L.J. 1395, 1400 (1975). John H. Ely cites the example of one Congressman who stated that "[w]hen hard decisions have to be made, we pass the buck to the agencies with vaguely worded statutes." JOHN H. ELY, DEMOCRACY AND DISTRUST 131-32 (1980). The same point is underscored by recent pluralist and public choice theory. For example, pluralists have argued that there is sometimes a need to "precommit" government to a course of action by issuing a mandate to an agency, since the political marketplace tends otherwise to be dominated by the concerns of current participants and special interest groups, at the expense of the public imterest and future generations. See CAss R. SUNSTEIN, AFTER THE RIGHTS REVolution, 49, 55-60, 67-68 (1990); see also Dwyer, supra note 60 , at $233,242-50$ (explaining that legislators prefer to cast symbolic votes regarding hazardous pollutants and leave unresolved questions to courts or agencies).

197. One of the central premises of this Comment is that the primary federal enforcement agency, the Environmental Protection Agency, is a capable agency and has proven worthy of this trust when given clear directives from Congress that permit it to exercise its mandate independent from political forces within either the executive or the legislative branch.

198. Apparently, Congress has attempted to do so in a limited way in the 1990 Amendments to the Clean Air Act. See infra Section III.D.

199. "Inpossibility" in this context uneans that the agency has determined that ensuring attaininent by the deadlines would be too costly for society to bear. 


\section{III}

\section{The Use of Severability Clauses as an Alternative MEANS OF STATUTORY INTERPRETATION}

The application of severability clauses to unattainable statutory deadlines is indeed the best way to "interpret" aspirational statutes. In fact, to apply severability clauses, Congress need neither change the way it writes statutes nor abandon aspirational legislation. What is required is inerely that a standard feature of legislation-namely, the severability clause-be interpreted to sever obsolete deadlines. In this sense, the apphication of severability clauses acts as a form of statutory interpretation.

This solution to the attainment deadline dilemma is in keeping with the values most commonly associated with the "legal process" moveinent: the need for a considered opinion consistent with the statute's language and, where the language is vague, with the statute's governing principle or purpose (e.g., to ensure clean air or water). This approach can therefore be categorized as "functional," or as "principled functional." 200

In this Part, I consider the proposed application of severability as a forin of statutory interpretation and coinpare it to two familiar approaches to statutory interpretation-dynainic interpretation and strict textuahisin. ${ }^{201}$ Although my discussion of these alternative approaches is necessarily somewhat siniplified, it illuminates how the severability solution would fit within the current scholarly debate over statutory interpretation. The Part concludes with a discussion of how Congress atteinpted to solve the attaimment date dilemma in the Clean Air Act Amendments of 1990.

\section{A. Interpreting the Statute Dynamically}

Professor William Eskridge has spearheaded a movement ${ }^{202}$ in legal scliolarship that believes traditional doctrines of statutory interpretation are "strikingly outdated." $203 \mathrm{He}$ suggests that interpretation is not a static endeavor, as traditional doctrine would suggest, but is ratler an inherently dynainic process. As Eskridge explains, "Interpretation is not

200. It may also be categorized even as an expression of the "new" legal process approach. See Daniel B. Rodriguez, The Substance of the New Legal Process, 77 CALIF. L. REv. 919, 940-46 (1989) (book review).

201. Some scholars have suggested that statutory interpretation doctrine "continues to reflect a basic dichotomy between textualist and intentionalist interpretive approaches." Id. at 929. Therefore, choosing approaches from either end of the interpretive spectrum reflects, to some degree, the current debate.

202. E.g., William N. Eskridge, Jr., Dynamic Statutory Interpretation, 135 U. PA. L. REV. 1479 (1987) [hereinafter Eskridge, Dynamic Statutory Interpretation]; William N. Eskridge, Jr., Spinning Legislative Supremacy, 78 GEo. L.J. 319 (1989).

203. Eskridge, Dynamic Statutory Interpretation, supra note 202, at 1482. 
Inere exegesis to pinpoint historical meaning, but hermeneutics to apply that meaning to current problems and circumstances."204 This reasoning follows neatly froin Ronald Dworkin's theory that law is interpretation. ${ }^{205}$

In their text on legislation, Professors Eskridge and Frickey lay out the essentials of dynamic statutory interpretation:

[Dynamic] statutory interpretation involves the present-day interpreter's understanding and reconciliation of three perspectives no one of which will always control. The three perspectives relate to (1) the statutory text ... ([providing the] textual perspective); (2) the original legislative expectations surrounding the statute's creation, including compromises reached (historical perspective); and (3) the subsequent evolution of the statute and its present context, especially the ways in which the societal and legal environment of the statute has inaterially changed over time (evolutive perspective). ${ }^{206}$

For Eskridge, the heart of dynamic statutory interpretation is the "evolutive" perspective. This approach assumes that "as the societal, legal, and constitutional context of the statute changes, our interpretation of the statute may change."207 Dynamic interpretation is particularly well suited to the interpretation of regulatory statutes: "In the modern administrative state, the process of law creation, implementation, and interpretation is a synergistic process involving an ongoing dialogue among all branches of governinent, including the headless fourth branch - the administrative agencies."208 Although Eskridge introduced this interpretive approach in the area of civil rights, it could just as well be applied to aspirational environmental statutes where agencies are intimately involved in the creation and iniplenientation of legislation.

This suggestion, albeit witlout the label "dynamic statutory interpretation," lias been offered in the specific context of the 1977 Clean Air Act. Pliilip Reed asserts that the Act was actually a better law when the Agency adliered not to the letter of the law but to its own understanding of what could be aclieved. He argues that althougl the vehicle that EPA created for implenienting the Clean Air Act bore little reseinblance to congressional blueprints, "[a]t least it addresse[d] in a facially rational way sonie issues that Congress did not face in 1977, such as what to do witl widespread violations of the 1982 attainment deadline."209

Professor Jolin Dwyer lias also suggested that dynanic interpreta-

204. Id.

205. See Ronald Dworkin, Law's Empire 413 (1986) ("What is law? . . . It is an interpretive, self-reflective attitude addressed to politics in the broadest sense.").

206. William N. Eskridge, JR., \& Philip P. Frickey, Cases and Materials on Legislation: Statutes and the Creation of Public Policy 6 I6 (1988).

207. Id.

208. Rodriguez, supra note 200 , at 928.

209. Reed, supra note 9, at 10,038 . 
tion is particularly well suited to aspirational statutes such as the Clean Air Act. Focusing on the regulation of hazardous airborne pollutants, Dwyer suggests that "[i]n order to provide useful regulatory instrnctions, symbolic statutes must evolve, not only through episodic legislative amendments, but also through agency interpretation influenced in part by current legislative judgment."210 $\mathrm{He}$ demonstrates quite convincingly that EPA is already deeply involved in the lawmaking process. He argues that the Agency should be permitted wider latitude in giving functional ineaning to substantive statutory provisions. ${ }^{211}$ The active interchange between Congress and EPA, he asserts, will keep the Agency in check.

Dwyer advocates judicial deference to agency reformulations of aspirational statutes generally. Agreeing with Colin Diver, Dwyer suggests that "agencies are better equipped than courts to unearth the legislature's purposes, understand the expectations of various audiences of the statute, and recognize and make adjustments for the behavioral consequences of different interpretations."212 Furthermore, one need not worry about pro-industry bias in this particular case because EPA is not a captured agency. ${ }^{213}$

Dwyer also suggests that a deferential approach in judicial review not ouly creates a better statute, but is also consistent with the cominands of Chevron. ${ }^{214}$ As the primary function of judicial review of agency decisions is to ensure that the agency remains within the bounds of statutory authority, the court may leave the policymaking aspect of interpreting aspirational statutes to the agency.

Dwyer asserts that according an agency greater flexibility to mold the dictates of a statute is not necessarily contrary to a proper judicial role. This position echoes that of Martin Shapiro, an expert in administrative law, who believes that agencies should be allowed to act as subordinate legislatures so long as they remain within congressional constraints. $^{215}$ For Shapiro, judicial review serves to ensure that agencies do not exceed these bounds.

Applying dynamic statutory interpretation to an attainment date dilemina would be relatively straightforward. Taking EPA's preDelaney, post-attainment date plan (contained in its 1987 deadline substi-

210. Dwyer, supra note 60, at 302.

211. See id. at 311 ("Agencies are better suited to reformulate the statute into workable regulations and standards.").

212. Id. (citing Colin Diver, Statutory Interpretation in the Administrative State, 133 U. PA. L. REv. 549, 574-78 (1985)).

213. A "captured agency" is one that identifies more with the interests of the group it is charged with regulating than with the public. Id. at 309.

214. Id. at 313-14.

215. Martin Shapiro, Who Guards the Guardians? Judicial Control of ADMINISTRATION 171 (1988). 
tution policy statement ${ }^{216}$ and the 1988 FIP for Los Angeles ${ }^{217}$ ) as an example, a court employing this method would consider Eskridge's textual, historical, and evolutive perspectives. First, adopting the textual perspective, the court would conclude that the statute did not provide for the post-attainment date dilemma. Second, an investigation of the statute froin the historical perspective would probably shed very little additional hight on the problem. Third, the court would have two options in examining the statute froin the evolutive perspective. It could investigate how the statute has evolved since its enactment--through legal interpretations and regulations-and consider what the present circumstances require. Or the court could defer to EPA on the grounds that the Agency, not the court, is in the better position to employ the evolutive perspective. Although Eskridge and other commentators are concerned primarily with the use of the evolutive perspective by courts, it is unlikely that they would object to judicial deference to an agency that can make better use of the evolutive perspective. In fact, Dwyer's arguments in particular seem to suggest this option.

The three-step process, therefore, inost likely would result in judicial deference to agency interpretation. If called upon to review EPA's general post-attainment policy, a court employmg this metliod of interpretation would have applied a standard of reasonableness that took into account dynamic interpretation. In short, a court would inost likely have held that the Agency's substitution policy was a reasonable dynamic statutory interpretation of the 1977 Clean Air Act.

Although Eskridge and others argue that botli the Supreme Court and lower courts already employ dynamic statutory interpretation, ${ }^{218}$ no court has opeuly avowed this practice. This fact, in and of itself, does not refute the possible usefulness of such an approach. New methods of statutory imterpretation often creep into the opmions of the judiciary far too slowly. For example, "plain meaning" was once the established norm until functionahism first began to appear in "plam meaning" decisions and eventually became recoguized as a separate school of interpretation acceptable in its own right. Moreover, statutory interpretation in judicial decisions rarely reflects one approacl exclusively. ${ }^{219}$

Although historical precedent may not provide adequate justification for hesitating to embrace dynamic statutory interpretation, history does suggest some advantages to slow mcorporation of this technique into judicial opinions. Turnimg again to the Los Angeles example: were

216. 52 Fed. Reg. 45,044 (1987).

217. Id. at 49,494 .

218. E.g., William N. Eskridge, Jr., Reneging on History? Playing the Court/Congress/President Civil Rights Game, 79 CALIF. L. REv. 613, 616 (1991).

219. See West Virginia Univ. Hosps., Inc. v. Casey, 111 S. Ct. 1138, 1153-56 (1991) (Stevens, J., dissenting) (documenting the Court's vacillation between approaches); EsKRIDGE \& FRICKEY, supra note 206 , at $592-93$ (discussing the various statutory approaches). 
a court to have approved the 1988 FIP on the basis of a dynamic interpretation of the statute, there is no question that this would have constituted a dramatically new mode of statutory construction. Congress, however, had enacted the 1977 Clean Air Act under the assumption that it would be interpreted according to traditional canons of interpretation. If we value the integrity of legislative decisionmaking, we inust conclude that such a volte-face by the courts (no matter what new interpretation is reached) is invalid because it demes Congress a fair opportunity to prepare in advance for such a contingency. In contrast, a slower incorporation of new interpretive approaches by courts signals to the legislature that it should consider these approaches in drafting its bills. A lack-ofnotice objection would, of course, be inoot if Congress had been soinehow aware when it enacted the bill into law that a new interpretation of its legislation was going to be apphed.

A further objection to the use of dynamic statutory interpretation is that Congress did not explicitly include provisions for either dynamic judicial review or judicial deference to agency dynamic interpretation in the statute.

The severability solution proposed in this Comment shares inany of the advantages of the dynamic approach while avoiding inost of its pitfalls. Applying the language that reniains after the deadlines are severed froin a statute gives agency officials the discretion to consider changed circumstances, developing teclınology, and evolving political constramts. The severability solution, noreover, avoids delegation doctrine and separation-of-powers problems by providing agencies with particular frameworks, authorized by Congress, within which to develop their regulations. Finally, the applicability of severability clauses provides for traditional reasonableness review by courts, but would not incur any of the transitional costs of the more dramatic dynamic interpretation solution.

\section{B. Forcing Congress to Act}

At the opposite end of the spectrun froin dynamic statutory interpretation is strict textualisin. Whereas dynamic statutory interpretation operates to make a statute work by leaving policy decisions to the entity best suited to handle it, textualism operates inore narrowly to inplement ouly what Congress has expressly enacted. Stated inost simply, textualism is based on the principle that only the common ("plain") ineaning of statutory language is controlling ${ }^{220}$ because this is the ouly interpretation

220. The following Supreme Court cases adhere to the "plain meaning" rule: Griffin v. Oceanic Contractors, Inc., 458 U.S. 564, 570 (1982); Consumer Prod. Safety Comm'n v. GTE Sylvania, 447 U.S. 102, 108 (1980); TVA v. Hill, 437 U.S. 153, 173 (1978). Although the Supreme Court has employed the textualist plain meaning rule in these and other opinions and appears to be leaning increasingly in this direction (due in part to the influence of Justice Scalia), it has not gone so far as 
that Congress has enacted into law. Thus, legislative history, current legislative preferences, and, to a lesser extent, even changed circuinstances do not matter to the textualist. Where the language is clear, textualists demand that a court stop at this threshold without einbarking on a deeper examination of whether the result of the language's application is consistent with Congress' underlying purpose. ${ }^{221}$

Had a textualist been asked to evaluate EPA's post-attaininent date pollution control strategy (contained in its 1987 deadline substitution pohicy and its 1988 FIP for Los Angeles), that person undoubtedly would have had two grounds on which to conclude that the strategy was flawed. First, given that the statute does not provide for such planning, a textualist would have concluded that such planning could not take place-it would exceed the Agency's statutory inandate. Second, the textuahist could also have concluded that because the attainment deadlines are specific and clear, they unust be enforced as written. If the attaininent deadlines specified in the statute had passed, enforcenient would mean immediate coinphance. The only circumstance in which a textualist would permit failure to enforce the statutory deadlines is where enforcement wonld produce absurd results. Moreover, it is likely that the results would have to be particularly severe for a textualist to agree to the avoidance of enforcement. Whichever reasoning that textuahist might have employed, he or she definitely would have objected to any deadline substitution policy since such a policy would require an agency or a court to reinove enacted statutory language and replace it with alternative language that had not been enacted by Congress.

As this discussion suggests, a textualist faced witl the attaininent deadline dilemma presented by the 1977 Clean Air Act would either have enforced the deadlines as written or, where severe dislocation would resnlt from such enforcement, would have failed to enforce the deadline. No post-attamment date planning would have taken place. Essentially, this approach would have meant that nothing would happen until Congress acted to amend the Act. This result would have comported well with the textualists' general belief that our institutions of government

to apply this rule in all, or even in most, of its recent cases. See West Virginia Univ. Hosps., $111 \mathrm{~S}$. Ct. at 1153-54 (Stevens, J., dissenting) ("In recent years the Court has vacillated between a purely literal approacl to the task of statutory interpretation and an approach that seeks guidance from listorical context, legislative history, and prior cases identifying the purpose that motivated the legislation."). Justice Scalia clearly favors the plain meaning approach:

The best evidence of . . [ [a statute's] purpose is the statutory text adopted by both Houses of Congress and submitted to the President. Where that contains a phrase that is unambiguous-that has a clearly accepted ineaning in both legislative and judicial practice-we do not permit it to be expanded or contradicted by the statements of individual legislators or committees during the course of the enactinent process.

$111 \mathrm{~S}$. Ct. at 1147.

221. See Griffin, 458 U.S. at 571 ("There is, of course, no more persuasive evidence of the purpose of a statute than the words by whicl the legislature undertook to give expression to its wishes.' ") (quoting United States v. Ameriean Trucking Ass'ns, Inc., 310 U.S. 534, 543 (1940)). 
must be held to the roles assigned them by the Constitution. ${ }^{222}$ Indeed, it could be argued that making policy decisions-especially the hard choices-is what Congress, a representative body sensitive to public opinion, is supposed to do under our constitutional, tripartite system of government and that forcing decisionmaking back on congressional actors, where it belongs, would actually encourage greater democracy.

However, in the context of the post-attainment period under the 1977 Act, this "remand" to Congress would probably not have produced very satisfactory results. Prior to the 1990 amendinent of the Clean Air Act, Congress had been wrangling over clean air pohicy for nine years. It is highly unlikely that judicial invalidation of some of the 1977 Clean Air Act deadlines due to absurdity or judicial invalidation of agency postattainment date planning could have forced Congress to resolve the difficult issue of cleaning up the nation's air any more quickly than it did. In the interim, no planning for attainment would have taken place and, as a consequence, hittle progress in cleaning the air would likely have occurred.

Even if a remand to Congress would have sped the much-needed amendment of the Clean Air Act, this approach is probably seriously flawed, for it may well be inappropriate for courts to set the legislative agenda by creating crisis situations. By forcing Congress to examine one problein, a court necessarily interferes with legislative priority-setting and creates a perfect scenario for hasty and flawed decisionmaking. Severability, im contrast, does not foist an issue onto the legislative agenda so suddenly that an irresponsible result ensues or that another equally or more important issue is set aside. Indeed, it permits Congress to delay amending a statute if it has more pressing matters to attend to.

Moreover, given the reelection maximizing behavior of the majority of the congressional meinbership, it may be unrealistic to assuine that its members will ever confront the hard choices of environinental regulation. Whichever choice they make between deceleration of economic developinent and a less healthful environinent simply will not be received favorably by a segment of their constituents. In the 1977 Clean Air Act, for example, Congress ostensibly intended to provide maximum protection for hnman health, yet it did not address the economic costs and social adjustments necessary to attain perfectly safe air.

In contrast to the overly idealistic stance of the textuahst argument, the severabihity solution takes into account the foibles of legislative politics. The inclusion of a severability clause essentially constitutes a congressional nod to reahity. It allows Congress to reap the benefits of

222. See, e.g., Casey, $111 \mathrm{~S}$. Ct. at 1148 (because it is not part of the Court's judicial function, the Court may not rectify statutory omissions or inconsistent policy); OFFICE OF LEGAL POLICY, U.S. DEP'T OF JUSTICE, supra note 155 , at 39-45. 
protecting human health while providing, through moderate sleight of hand, for soine balancing of health benefits against econoinic costs.

\section{Why an Ex Ante Solution Is Best}

Both textualism and dynamic statutory interpretation are methods of interpreting statutes after they have been enacted. In contrast, the severability solution-einploying as it does actual statutory languagerequires action before legislation is enacted. Congress has to draft statutes with severability clauses and make manifest its intent that these be used to avoid attainment deadline dilemmas. This should please textualists, who deinand that legislative decisions be left to the legislature: Congress would make a solution available to agencies and courts within the confines of the statutory text. Moreover, Congress would remain in control of the amount of power it delegates, in contrast to the dynamic approach in which Congress loses virtually all control over the extent to which courts may reformulate statutes.

\section{An Alternative Approach: Creating a Framework for Revision}

In its 1990 Amendments to the Clean Air Act, Congress provided for the possibility that certain nonattainment areas may not attain the NAAQS by the required deadlines. Unlike the severabihty solution proposed here, the plan implemented by Congress is essentially a deadline substitution plan in which the controls exerted im a nonattainment area are ratcheted up at each instance of failure to meet a final attainment deadline. This characterization, however, scarcely does justice to what is an exceedingly complex statutory scheine. To understand the post-deadline provisions in the 1990 Amendments more fully and how they coinpare to the severability solution, this Section will briefly summarize the major points of these provisions.

The 1990 Amendinents greatly expanded part D, which covers plans for nonattainment areas. As revised, part D now provides a general provision for nonattainment plans ${ }^{223}$ as well as particular provisions for plans governing areas that are out of attainment for any of the currently regulated NAAQS: ozone (subpart 2); carbon inonoxide (subpart 3); particulate matter (subpart 4); and sulfur oxides, nitrogen dioxide, or lead (subpart 5). The general provisions do not apply to "nonattainment areas for which attainment dates are specifically provided in other provisions of this part."224

Although less complex than the requirements spelled out in each subpart, the general provisions are also quite detailed. The attaininent

223. 42 U.S.C. $\S 7502$ (Supp. II 1990).

224. Id. § 7502(a)(2)(D). 
deadline ${ }^{225}$ for these nonattainment areas is the date by which attainment can be achieved as "expeditiously as practicable, but no later than 5 years from the date such area was designated nonattainment."226 The Administrator may extend the attainment date by up to five additional years, if she deems it appropriate "considering the severity of nonattainment and the availability and feasibility of pollution control measures."227 Two additional extensions of one year each are also available at the Administrator's discretion if she finds that the state has complied with all plan requirements and has exceeded the relevant NAAQS only a minimal number of times in the past year. 228

Under the general provisions, each plan must provide contingency measures that will be triggered automatically by the failure to attain the particular standard by the applicable attainment date. ${ }^{229}$ The most innovative part of these general provisions is the section concerning the consequences for failure to attain the air quality standard. Within six months after the passage of the attainment deadline, the Administrator must determine if the area has reached attamment. ${ }^{230}$ If it has not, the state must subimit a revision to its SIP that includes "all measures that can be feasibly implemented in the area im light of technological achievability, costs, and any nonair quality and other air quality-related health and environmental impacts." ${ }^{231}$ By increasing the measures from RACT, which is all that is required in the pre-attamment deadhine plans, ${ }^{232}$ to all those that can be "feasibly implemented," the section ratchets up the control measures required.

Under these general provisions, this post-deadline revision to the SIP inust also contain new deadlines. These deadlines are computed under the same sclieme as the original ones-five years maximum, five years additional at the Administrator's discretion, and so on-except that the period runs from the date when the Administrator gives notice of the failure to attain rather than from the date the area is classified as being in nonattainınent. ${ }^{233}$ For this reason, I characterize the general provisions' deadline solution as a deadline-substitution solution.

The individual subparts that prescribe the plan requirements for areas out of attainment for ozone, carbon monoxide, or particulate mat-

225. "Attainment" continues to refer to the attainment of the primary national ambient air quality standards for a particular pollutant. See id. $\S 7502$ (a)(2)(A) ("The attainment date for an area designated nonattainment with respect to a national primary ambient air quality standard shall be the date by which attainment can be achieved as expeditiously as practicable ....").

226. Id.

227. Id.

228. Id. $\S 7502(\mathrm{a})(2)(\mathrm{C})$.

229. Id. $\S 7502$ (c)(9).

230. Id. $\$ 7509$ (c).

231. Id. $\S 7509$ (d)(2).

232. Id. $\S 7502$ (c)(1).

233. Id. $\S 7509(\mathrm{~d})(3)$. 
ter follow this same pattern of ratcheting up the required controls and substituting deadlines. These three subparts specify that the area be categorized according to the severity of nonattainınent. ${ }^{234}$ This categorization, in turn, determines which requirements and attainment deadline apply to the area's plan. ${ }^{235}$ Under these three subparts, if the area fails to attain the relevant air quality standard by the prescribed deadline, it may be reclassified into a category containing more stringent control measures. ${ }^{236}$ This reclassification not only triggers additional control measures, but also substitutes the deadline applicable to the new classification. In addition, $m$ many circumstances, once the deadline passes, a fixed percentage reduction $\mathrm{m}$ ambient air concentration of the relevant pollutant will be required over a period of time..$^{237}$

This deadline substitution with concurrent increased control measures is certainly an improvement over the 1977 Act, which failed to address the attainment deadline dilemma. By providing the Administrator with specific commands regarding post-attainment date plans, Congress dictates to the Agency exactly what must be done and how. This control will please those concerned about agency capture, inaction, or unaccountability.

It is less clear, however, whether this additional control is necessary or even advisable. There is ample evidence that EPA is not a captured agency and that it has acted as aggressively as it could have in fulfilling its nondiscretionary duties, given the demands of the Act and the severity of the pollution problems in some areas. The root problem with attainment deadlines is that they involve predictions, often contingent upon teclinologies that have not been invented or tested, about when a hypothetical situation (for example, the attainment of air quality standards) can occur.

The 1990 Amendments themselves contain attainment deadlines now twenty years away. They thus postpone the problem but do not eliminate it. Substituting a new statutory deadline for an obsolete one works only if Congress is able to take the time and trouble to intervene each time a new post-attaminent period is reached. The underlying problem is that no satisfactory statutory provision exists for these post-attainment periods until Congress acts. Permitting an agency that has experience in the relevant area, that has reviewed all implementation plans, that is familiar with the reasons for any failures to attain the initial attainment deadline, and that is aware of current teclinological and eco-

234. In the case of ozone nonattainment, there are five possible categorizations: marginal, moderate, serious, severe, and extreme. Id. § 7511(a)(1). Carbon monoxide nonattainment areas and particnlate matter nonattainment arcas must be categorized either moderate or serious. Id. $\S \S 7512(\mathrm{a})(1), 7513(\mathrm{a})-(\mathrm{b})$.

235. See id. §§ 7511a-7513a.

236. See id. $\S \S 7511(\mathrm{~b})(2), 7512(\mathrm{~b})(2), 7513(\mathrm{~b})(2)$.

237. See id. $\S \S 7511(\mathrm{~b})(4), 7512 \mathrm{a}(\mathrm{g}), 7513 \mathrm{a}(\mathrm{d})$. 
nomic conditions, to devise an appropriate plan and deadlines is a more sensible approach.

Some may object that permitting an agency to decide on deadlines delegates too much power to the agency. This power, however, is already in the Agency's hands since it has discretion (subject to judicial reasonableness review) to define the RACT and "as expeditiously as practicable" requireinents at the core of the Act. The substituted deadlines of the 1990 Amendments, in contrast, are unnecessary and substantially unenforceable. Substituting deadlines merely reinforces a fallacious belief that they are meaningful. The actuality is that, given the varying pace of teclinological development and the uncertainty surrounding control techniques, the deadlines are largely superfluous.

The severability solution would not perpetuate the deadline myth. It permits agencies to plan realistically according to the substantive mandates of organic legislation. In the case of the Clean Air Act, the removal of attainment deadlines from the statute, something that is politically unpalatable to Congress, would not be necessary because the deadlines could be severed in the course of enforcement if the initial timeframe proves inaccurate and detrimental.

\section{CONCLUSION}

This Comment has described the attainment date dileinma, a problem common to many environmental statutes. Environmental statutes containimg unrealistic attainment deadlimes based upon aspirational or technology-forcing goals almost mevitably lead to the dilemma. Given the political costs associated with determinimg realistic goals, however, it is unlikely that Congress will stop enacting aspirational and technologyforcing statutes that effectively leave the hard choices to the implementing agency.

Judicial and administrative solutions to the dileinma have so far proved unsatisfactory. Areas close to attainment have generally been perimitted after the deadlines to continue their progress towards attainment at their customary pacc, so long as the progress is truly as "expeditious[] as practicable." Although superficially attractive, this way of resolving "easy" cases fails to reach any principled basis for dealing with the statutory deadlines or for explaining why ouly the part $\mathrm{D}$ requirements operate after the deadlines pass. Planning for air quality attainment in areas far from this goal illustrates the failure of the "easy case" approach, because a court's equitable powers are hardly a sufficient basis on which to justify extending statutory deadlines decades into the future.

The solution proposed in this Coinment would begin at the legislative drafting stage by inaking use of a common statutory provision. Its implementation would not require any fundaniental change in congressional politics, nor would its use be novel to courts faced with interpret- 
ing and applying statutes in post-attainment date scenarios. The familiarity of severability clauses is a decided advantage and is likely to make the solution especially attractive to Congress. Where legislative history does not contradict the presumption in favor of severability-and this Comment suggests that Congress should explicitly endorse this presumption-the clause may be employed.

The severability solution proves its viability when hypothetically apphied to the dilemmas that arose out of the 1977 Clean Air Act. Unrealistic attainment dates could have been invalidated by a court once they became obsolete on the grounds of impossibility or because they would have produced absurd results. Since attainment dates were only part of a larger set of requirements (for example, RACT), their removal would have left the courts and the Agency with adequate law to apply and would not have disturbed the statute's fundamental operation.

Because severance involves making use of the remaining portion of the statute, it is truer to the statute's language than a dynamic statutory interpretive approach, yet it avoids the pitfalls of the excessive literalism associated with textuahsm. In addition, severance permits both the courts and Congress to mamtain their current roles; in contrast, dynamic statutory imterpretation results in an untold expansion of judicial lawmaking power, and textualism imterferes with legislative powers by forcing hard decisions on Congress even when Congress may be unwilling to act.

The simplicity, effectiveness, and political sophistication of the severance solution therefore make it the best option for dealing with the attainment deadline dileinma. 